\title{
Development of an Item Bank to Measure Medication Adherence: Systematic Review
}

Yu Heng Kwan ${ }^{1,2^{*}}$, PhD; Livia Jia Yi Oo ${ }^{2 *}$, BSc; Dionne Hui Fang Loh ${ }^{3 *}$, BEng; Jie Kie Phang ${ }^{4}$, BSc; Si Dun Weng ${ }^{2}$, BSc; Dan V Blalock ${ }^{5,6}$, PhD; Eng Hui Chew ${ }^{2}$, PhD; Kai Zhen Yap ${ }^{2}, \mathrm{PhD}$; Corrinne Yong Koon Tan ${ }^{7}, \mathrm{MBA}$; Sungwon Yoon $^{1,3}$, PhD; Warren Fong ${ }^{4,8,9}$, FAMS; Truls Østbye ${ }^{1 *}$, PhD; Lian Leng Low ${ }^{3,10,11^{*}}$, FCFP(S); Hayden Barry Bosworth $^{5,6,12,13^{*}}, \mathrm{PhD} ;$ Julian Thumboo ${ }^{1,4,9^{*}}$, FRCP

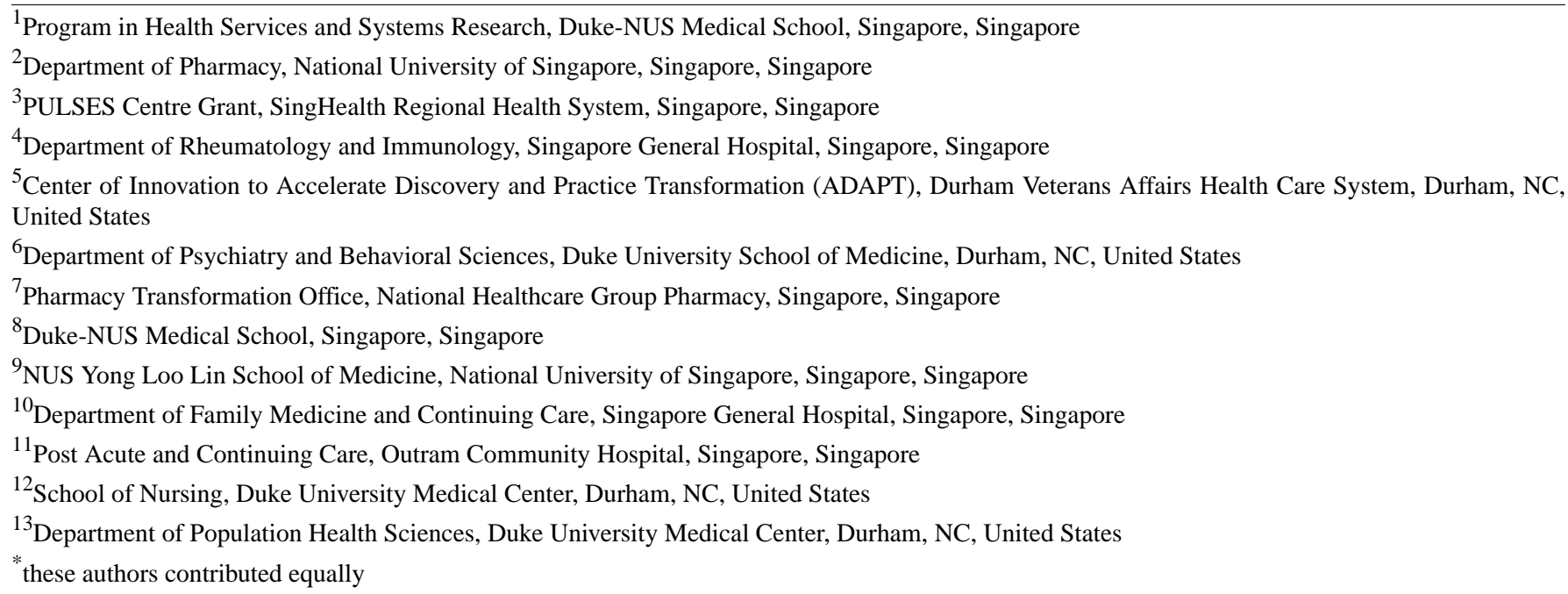

Corresponding Author:

Yu Heng Kwan, $\mathrm{PhD}$

Program in Health Services and Systems Research

Duke-NUS Medical School

8 College Road

Singapore, 169857

Singapore

Phone: 6563778465

Email: yuheng@u.duke.nus.edu

\section{Abstract}

Background: Medication adherence is important in managing the progression of chronic diseases. A promising approach to reduce cognitive burden when measuring medication adherence lies in the use of computer - adaptive tests (CATs) or in the development of shorter patient-reported outcome measures (PROMs). However, the lack of an item bank currently hampers this progress.

Objective: We aim to develop an item bank to measure general medication adherence.

Methods: Using the preferred reporting items for systematic review and meta-analysis (PRISMA), articles published before October 2019 were retrieved from PubMed, Embase, CINAHL, the Cochrane Library, and Web of Science. Items from existing PROMs were classified and selected ("binned" and "winnowed") according to standards published by the Patient-Reported Outcomes Measurement Information System (PROMIS) Cooperative Group.

Results: A total of 126 unique PROMs were identified from 213 studies in 48 countries. Items from the literature review (47 PROMs with 579 items for which permission has been obtained) underwent binning and winnowing. This resulted in 421 candidate items (77 extent of adherence and 344 reasons for adherence).

Conclusions: We developed an item bank for measuring general medication adherence using items from validated PROMs. This will allow researchers to create new PROMs from selected items and provide the foundation to develop CATs. 
(J Med Internet Res 2020;22(10):e19089) doi: 10.2196/19089

\section{KEYWORDS}

systematic review; patient-reported outcome measures; item bank; adherence

\section{Introduction}

Medication adherence is defined as the degree to which a patient's behavior corresponds with the agreed recommendations from a health care provider [1]. The average adherence rate ranges from $50 \%$ among patients suffering from chronic diseases in developed countries [2] to $79 \%$ among those receiving medical treatment prescribed by a nonpsychiatrist physician $[3,4]$. Nonetheless, medication nonadherence is recognized as a significant public health issue since it can result in poor health outcomes and increased health care costs [5]. Medication adherence, which is important in managing the progression of chronic diseases, may be assessed using patient-reported outcome measures (PROMs). Using PROMs to measure medication adherence may be susceptible to a social desirability bias [6]; however, PROMs are much more practical in daily clinical practice because of their relatively low cost and ease of administration as compared to pill counting or an electronic monitoring system such as the medication event monitoring system (MEMS).

PROMs are measures of the status of a patient's health condition that originate directly from the patient, without interpretation of the patient's response by a caregiver or physician [7]. Numerous PROMs have been developed and validated to measure medication adherence. These include instruments such as the Medication Adherence Report Scale (MARS) [8], the 4and 8-item Morisky Medication Adherence Scale (MMAS-4 and MMAS-8) [9], the Hill-Bone Medication Adherence (HBMA) scale [10], and the Domains of Subjective Extent of Nonadherence (DOSE-Nonadherence) scale [11]. However, most self-report measures that were developed using classical test theory $[12,13]$ are static and administered using a common item set regardless of the respondent's level of medication adherence [14]. Since patients are asked the same questions repeatedly, this approach results in significant cognitive burden [15], low precision [16], a waste of the patients' time, as well as a lack of additional, new information [17].

A novel approach to overcome this limitation lies in the use of a computer - adaptive test (CAT) to create new PROMs for measuring medication adherence. A CAT is a system for tailoring a test, whereby the next item administered to the respondent is determined by and adaptive to the patient's response to the previously-administered item [18]. The Patient-Reported Outcomes Measurement Information System (PROMIS) was developed through a CAT and item response theory (IRT). Instead of focusing on the entire test, IRT shifts the focus to the individual questions [19]. The use of IRT with a CAT allows for the identification, individualization, and administration of a feasible number of items that are likely to offer the highest precision [20]. In order to achieve higher precision, PROMIS investigators were required to identify and develop items covering the full range of experience in the domains the instrument was intended to measure (ie, content validity) [14]. Thus, the first step to a CAT is an item bank consisting of questions from medication adherence PROMs. Therefore, this systematic literature review aims to identify and develop an item bank through a comprehensive summary of the questions from validated medication adherence PROMs.

\section{Methods}

This systematic review was guided by the preferred reporting items for systematic review and meta-analysis (PRISMA) statement [21]; standards published by the PROMIS committee [22] were adapted in the development of the item bank.

\section{Search Strategy}

Articles published before October 2019 were retrieved from PubMed, Embase, CINAHL, the Cochrane Library, and Web of Science. A search strategy (Multimedia Appendix 1) of 4 components was used as follows: construct of interest, population, instrument, and measurement properties. The searches focused on medication adherence PROMs. Where available, the sensitivity of the searches was enhanced using search filters developed by Terwee et al [23], which involves a combination of search terms designed to retrieve studies on measurement properties of measurement instruments. The search records were downloaded into Endnote X9 (Clarivate Analytics), and any duplicates were removed.

\section{Article Selection}

All titles and abstracts were screened independently by 2 reviewers (LJYO and SDW). A third reviewer (YHK) was consulted when a disagreement arose between the 2 reviewers. For articles that were potentially relevant, the full text of these articles was independently reviewed by the same 2 reviewers for inclusion or exclusion.

Articles were included if they were full-text original publications in English that validated PROMs for medication adherence. Articles were excluded if the PROMs were completed by proxy, or if they were conference abstracts, expert opinions, narrative reviews, or not peer-reviewed. Animal and case studies, as well as non-English language studies, were also excluded. These exclusions were not used to construct the search strategy to avoid the omission of relevant articles.

\section{Data Extraction}

Where available, 2 reviewers (LJYO and SDW) extracted study population characteristics (sample size, age, gender, and country) data from the articles.

\section{Identification of Existing PROMs for Inclusion}

The names of PROMs extracted from the previous step were consolidated. In order to optimize the number of relevant items for evaluation, the most recent and exhaustive version was included when multiple versions of the same PROM were found across the included studies. 
For the assessment of PROMs for inclusion, reviewers obtained information regarding the PROM through internet searches. Copies of the shortlisted PROMs were retrieved either from sources available to the public (ie, official websites or research publications) or by requesting copies from the developers or study investigators of these PROMs. Permission was obtained from the study investigators for the inclusion of the PROM into the item bank. Where possible, permission from the PROM developers was sought in the case that the study investigators were not in a position to provide consent due to claims of intellectual property. After the initial contact, 2 follow-up reminder emails were sent to the unresponsive study investigators. This resulted in a final list of PROMs from which items were extracted and evaluated.

\section{Item Classification (Binning)}

Item classification, or binning, refers to a systematic process for grouping items according to meaning and specific latent construct. This process aims to obtain a bin with the most exhaustive list of items, from which a smaller number of items may be chosen to adequately represent the bin. The number of items that would adequately represent a bin was not predetermined, as the purpose of this process was to identify sufficient items that encompass the meaning of the bin and to eliminate unnecessary redundancy in the pool of items [14].

Binning was done using terms in English, and each item was included in as many bins as was deemed fit. To ensure that the binning process was exhaustive, 2 independent reviewers (LJYO and DHFL) evaluated any one item for possible inclusion, and an item identified for inclusion to a bin by at least 1 reviewer was included in that bin.

A 2-stage process was carried out for binning. First-order binning was completed at the level of the domain: each item was evaluated for possible inclusion into (1) Extent of Adherence and/or (2) Reasons for Nonadherence. The domains were derived from the self-report measure developed by Voils et al [11].

For the Reasons for Nonadherence domain, second-order binning was completed at the level of the subdomain consisting of (1) social- and economic-related factors, (2) health care team and system-related factors, (3) therapy-related factors, (4) condition-related factors, and (5) patient-related factors. The subdomains were derived from the World Health Organisation (WHO) framework for medication adherence [2]. The framework has been widely used in various literature [24-32]. Second-order binning was not deemed to be necessary for the Extent of Adherence domain.

\section{Item Selection (Winnowing)}

The process of winnowing aims to narrow the large pool of items down to a representative set of items; this is done by identifying item characteristics that would either include or exclude items from the item bank based on the definition of the domains [14]. Winnowing was performed by 2 reviewers (LJYO and DHFL) independently assessing each bin, and items that best represented the respective domains were first selected. The process was carried out separately for each domain.

The following criteria were used to eliminate items from consideration [14]: (1) the content of the item was inconsistent with the definition of medication adherence, or with the scope of the extent of and reasons for medication adherence; (2) the item was semantically redundant with a previous item; (3) the content of the item was too narrow to be universally applicable; (4) the stem of the item was highly disease-specific, which reduces overall applicability and limits the adaptation of the item; (5) the item was confusing; and (6) the item was open-ended, which increases the difficulty of implementation.

After the pair of reviewers completed the item selection independently, a third reviewer (YHK), who is trained in measurement science and item banking and was not previously involved in the binning and winnowing process, was consulted to identify the items that best represented each domain, as well as the items for removal.

\section{Results}

\section{Search Results and Characteristics of the Included Articles}

A total of 51,426 studies were obtained from the database search, of which 8286 duplicates were excluded. A review of the titles and abstracts led to the exclusion of 42,836 studies. Subsequently, full-text review excluded 98 studies, with reasons provided in Figure 1. An additional 7 studies were identified through hand-searching of reference lists, resulting in 213 relevant validation studies for potential inclusion into the item bank. The characteristics of the relevant studies are presented in Table 1. 
Figure 1. Flow chart of the systematic literature review.

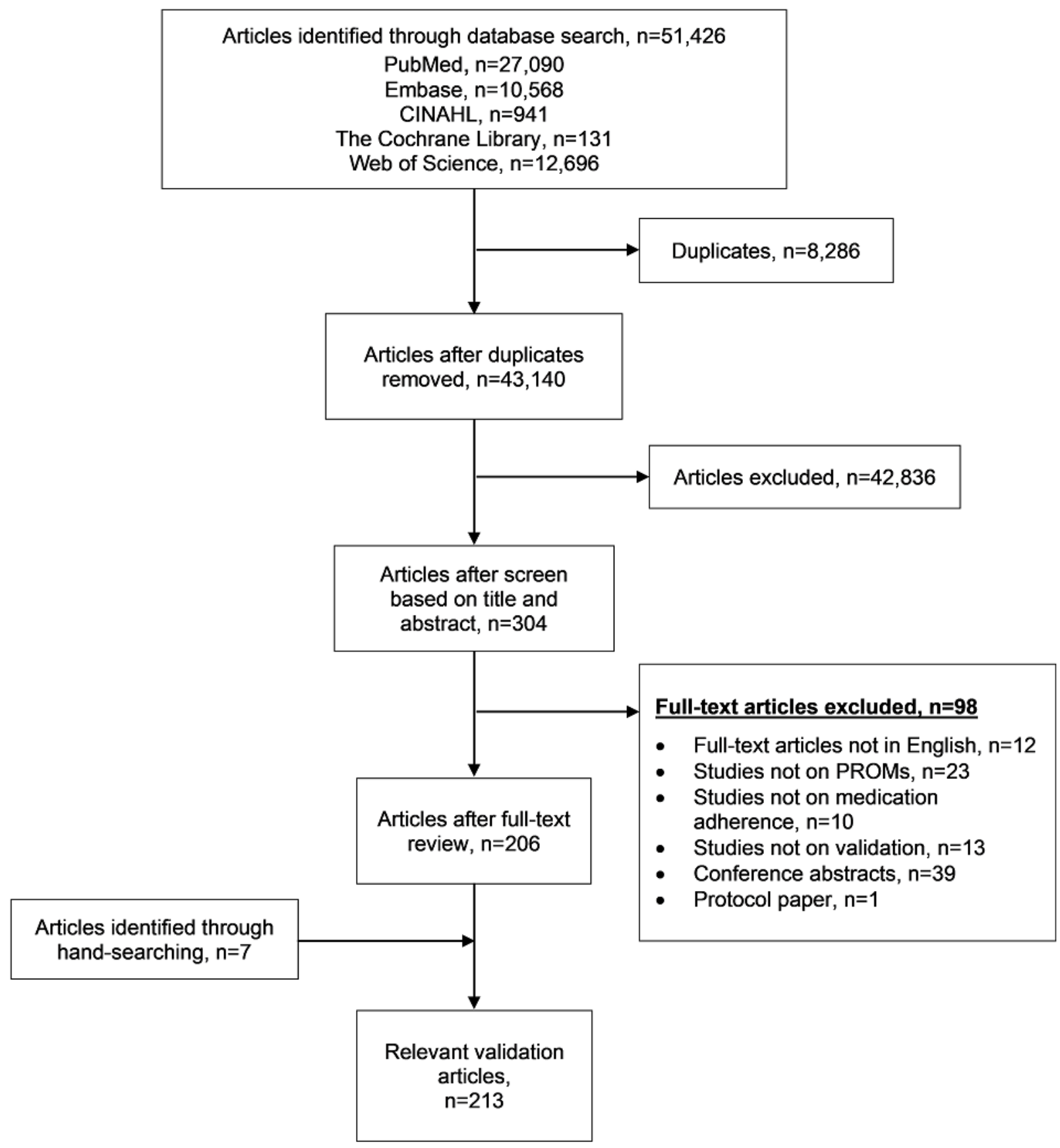


Table 1. Characteristics of studies for potential inclusion into the item bank $(n=213)$.

\begin{tabular}{|c|c|}
\hline General Characteristics & Values \\
\hline Number of unique countries involved & 48 \\
\hline Number of unique PROMs ${ }^{\mathrm{a}}$ studied & 126 \\
\hline \multicolumn{2}{|l|}{ Sample size, n (\%) } \\
\hline$<50$ & $17(8.0)$ \\
\hline $50-99$ & $31(14.6)$ \\
\hline $100-199$ & $64(30.0)$ \\
\hline $200-299$ & $30(14.1)$ \\
\hline $300-399$ & $22(10.3)$ \\
\hline $400-499$ & $15(7.0)$ \\
\hline$>500$ & $34(16.0)$ \\
\hline \multicolumn{2}{|l|}{ Mean age in years, $n(\%)$} \\
\hline $0<$ mean age $\leq 20$ & $9(4.2)$ \\
\hline $20<$ mean age $\leq 40$ & $28(13.2)$ \\
\hline $40<$ mean age $\leq 60$ & $101(47.4)$ \\
\hline $60<$ mean age $\leq 80$ & $54(25.4)$ \\
\hline$\geq 80$ & $2(0.9)$ \\
\hline Not reported ${ }^{b}$ & $19(8.9)$ \\
\hline \multicolumn{2}{|l|}{ Proportion of males, n (\%) } \\
\hline$<0.2$ & $15(7.0)$ \\
\hline $0.2 \leq x<0.4$ & $46(21.6)$ \\
\hline $0.4 \leq x<0.6$ & $77(36.2)$ \\
\hline $0.6 \leq x<0.8$ & $40(18.8)$ \\
\hline$\geq 0.8$ & $23(10.8)$ \\
\hline Not reported & $12(5.6)$ \\
\hline
\end{tabular}

${ }^{\text {a }}$ PROMs: patient-reported outcome measures.

${ }^{\mathrm{b}}$ Includes values in the form of median, range, or not reported.

\section{Identification of Existing PROMs for Inclusion}

The review of the included articles identified 126 unique PROMs measuring medication adherence, which were validated in 48 countries. A majority of the identified PROMs were self-administered questionnaires.

After obtaining written permission from the study investigators and PROM developers for the use of the items as part of the item bank, 47 PROMs from 53 studies were included in the item bank, as presented in Textbox 1. PROMs from the remaining 160 studies (Multimedia Appendix 2 [33-189]) were excluded due to a lack of consent. Among the 53 included studies, the Modified Drug Adherence Work-Up (M-DRAW) tool, the Reduced Glaucoma Treatment Compliance Assessment Tool (GTCAT), and the 3-Item Self-Report Measure for Medication Adherence were each evaluated in 2 studies; the General Medication Adherence Scale (GMAS) was evaluated in 3 studies; and DOSE-Nonadherence was evaluated in 4 studies. PROMs included were mostly developed and validated in English. A total of 579 items were collated from these PROMs, including 71 non-English items. 
Textbox 1. List of the patient-reported outcome measures (PROMs) that were included in the item bank. *Instruments which were not named; ** instruments developed/validated in non-English but have an existing English-translated version for publication purposes; ***instruments developed and/or validated in non-English.

\section{Generic PROMs}

- $\quad$ Diagnostic Adherence to Medication Scale (DAMS) [190] (6 items)

- $\quad$ 7-Item Adherence to Refills and Medications Scale (ARMS-7) [191]** (7 items)

- $\quad$ Adherence to Refills and Medications Scale (ARMS) [192] (12 items)

- $\quad$ Brief Medication Adherence Scale (BMAS) [193]** (10 items)

- $\quad$ Domains of Subjective Extent of Nonadherence (DOSE-Nonadherence) Scale [11,194-196] (21 items)

- $\quad$ Every Visit Adherence Questionnaire [197] (1 item)

- $\quad$ General Medication Adherence Scale (GMAS) [198-200] (11 items)

- $\quad$ Medication Adherence Estimation and Differentiation Scale (MEDS) [201] (16 items)

- $\quad$ Modified Drug Adherence Work-Up (M-DRAW) Tool [202,203] (14 items)

- $\quad$ Self-Reported Adherence (SERAD) Questionnaire [204]*** (2 items)

- $\quad$ Simplified Medication Adherence Questionnaire (SMAQ) [205] (6 items)

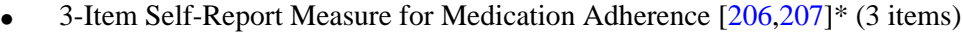

\section{Disease-Specific PROMs}

- $\quad$ 12-Item Medication Adherence Scale for Patients with Chronic Disease [208]* (12 items)

- $\quad$ 5-Item Compliance Questionnaire for Rheumatology (CQR5) [209] (5 items)

- $\quad$ Adult Asthma Adherence Questionnaire (AAAQ) [210] (5 items)

- $\quad$ Antidepressant Adherence Scale (AAS) [211] (4 items)

- $\quad$ Antipsychotic Medication Beliefs and Attitudes Scale (AMBAS) [212] (12 items)

- $\quad$ Assessment Scale for Treatment Compliance in Type 2 Diabetes Mellitus [213]* (30 items)

- $\quad$ Brief Evaluation of Medication Influences and Beliefs (BEMIB) [214] (8 items)

- $\quad$ Chinese and Western Medication Adherence Scale in Chronic Kidney Disease [215]* (18 items)

- $\quad$ Chinese Diabetes Medication Self-Efficacy Scale (CDMSS) [216]*** (19 items)

- $\quad$ Combination Antiretroviral Therapy Adherence Questionnaire [217]* (4 items)

- $\quad$ Diabetes Management Questionnaire (DMQ) [218] (21 items)

- $\quad$ Diabetes Medication Self-Efficacy Scale (DMSS) [219] (19 items)

- ICAMP Adherence Questionnaire [220] (10 items)

- $\quad$ Immunosuppressant Therapy Adherence Scale (ITAS) [221]*** (4 items)

- Iraqi Anti-Diabetic Medication Adherence Scale (IADMAS) [222] (8 items)

- $\quad$ IRT-30 [223] (10 items)

- $\quad$ Lasso-10 [223] (30 items)

- $\quad$ Measure for Intention to Adhere to HIV Treatment [224]* (14 items)

- $\quad$ Medication Adherence Self-Reports in Adults with Type 2 Diabetes [225]* (6 items)

- Medication Adherence Survey for Hemodialysis Patients [226]* (23 items)

- $\quad$ Multiple Sclerosis Treatment Adherence Questionnaire (MS-TAQ) [227] (11 items)

- $\quad$ Outcome Expectations for Osteoporosis Medication Adherence Scale in Chinese Immigrants (OEOMA-C) [228]** (5 items)

- $\quad$ Patient-Reported Measures Assessing Adherence Behaviors and Barriers in Patients Living with HIV [229]* (7 items)

- $\quad$ Perceived Barriers to Antiretroviral Therapy Adherence (PEDIA) Scale [230]** (18 items)

- $\quad$ Portuguese End-Stage Renal Disease Questionnaire (PESRD-AQ) [231]*** (46 items)

- $\quad$ Questionnaire for Adherence with Topical Treatments in Psoriasis (QATOP) [232] (9 items)

- $\quad$ Reduced Glaucoma Treatment Compliance Assessment Tool (GTCAT) [233,234] (28 items) 
- $\quad$ Risk of Nonadherence to Antibiotic Treatment Questionnaire [235]* (20 items)

- Self-Assessment Tool to Measure Imatinib Adherence in Patients with Chronic Myeloid Leukemia [236]* (10 items)

- Self-Efficacy for Osteoporosis Medication Adherence Scale in Chinese Immigrants (SEOMA-C) [228]** (14 items)

- $\quad$ Self-Report Measures in Assessing Antiretroviral Adherence [237]* (3 items)

- $\quad$ Self-Reported Compliance to Metered-Dose Inhalers Questionnaire [238]* (4 items)

- Self-Reported Questionnaire Assessing Adherence to Antiretroviral Medication [239]* (5 items)

- $\quad$ Test of the Adherence to Inhalers (TAI) [240] (12 items)

- Treatment Adherence Survey - Patient Version (TAS-P) [241] (16 items)

\section{Item Evaluation}

At the stage of winnowing, 319 items inconsistent with the definitions of the domains or subdomains were removed. The 2 independent reviewers achieved a $90.4 \%$ agreement on the items for removal. Most eliminated items were found to be highly disease-specific (eg,"I arrange my oral antidiabetic medication or insulin dose myself according to my food intake.”) or open-ended (eg,“How many doses did you miss?”).
In the Extent of Adherence, a total of 77 representative items were identified, while 344 items were included in the Reasons for Nonadherence, with an average of 70 items (SD 43.1; range 24-137) within each of the 5 dimensions. The breakdown of the number of items in each domain and subdomain is summarised in Table 2, and a representative table of the mapping of each item is presented in Multimedia Appendix 3. Binned and winnowed items that were granted approval by the study investigators or PROM developers to be openly listed in the item bank are presented in Multimedia Appendix 4.

Table 2. Summary of domains and the number of items in each bin.

\begin{tabular}{ll}
\hline Domain/subdomain & Number of items \\
\hline Extent of adherence & 77 \\
Reasons for adherence & 32 \\
Social and economic factors & 24 \\
Health care team and system-related factors & 37 \\
Condition-related factors & 114 \\
Therapy-related factors & 137 \\
Patient-related factors & \\
\hline
\end{tabular}

\section{Discussion}

This systematic review summarises the process of developing an item bank for the domain of general medication adherence. A multistep approach adapted from the PROMIS standards for the development of item banks [14] was used. In order to enhance the comprehensiveness of the item bank, items originating from both disease-specific and nondisease specific PROMs were considered and reviewed for inclusion. To the best of our knowledge, this is the first systematic review to collate items from various medication adherence PROMs into an item bank. As numerous PROMs have been developed and validated for use in the measurement of medication adherence, an item bank consisting of the most representative items may improve the relevance and precision of assessments [242].

The current item bank enables researchers to select items for the creation of new PROMs. The rare and highly disease-specific items were eliminated during the winnowing process; however, the items included in the item bank may be adapted for use in both specific patient groups and the general population. There have been conflicting results on the association between age and medical adherence, with some studies providing evidence of an association between younger age and nonadherence [243] and others showing an association between older age and nonadherence [244]. A CAT that was developed using IRT based on our item bank can potentially examine the changing pattern of medical adherence during a lifetime more precisely than traditional PROMs that are developed using classical test theory [245,246]. In addition, previous studies have shown that adherence to different medications may vary within the same individual [247,248]. We can potentially overcome this issue by specifying the type of medication in the question stem in the CAT.

Towards the use of the item bank in CATs, the next steps are to revise and review the items through cognitive interviews, to calibrate the items using IRT, and to evaluate the validity of test scores when the items are administered adaptively. The items that underwent binning and winnowing originated from various PROMs. They were created in varying styles, phrasings, and sentence structures, with different response options for each item, including dichotomous, Likert, and semantic differential scales. Due to the discordances among the items, the item revision process would be prudent to facilitate the administration of the items as 1 coherent test. Once fully developed, the resulting instrument may potentially improve measurement 
precision and allow for a reduction in assessment time [249] and, accordingly, patient cognitive burden. Furthermore, since the scores are directly comparable [250], such an instrument would allow health care providers to measure and compare the medication adherence of a patient from consult to consult. Alongside other clinical measures, such as symptom scores and quality of life scales, these measurements may enable physicians to detect issues in a patient's medication adherence, implement timely interventions, evaluate the effectiveness of the interventions, and make prompt modifications when necessary.

This study has several strengths; 5 databases, as well as sensitive search filters, were used to capture as many potentially relevant articles as possible. The rigor of this study was established using the PRISMA statement and PROMIS standards. The PRISMA statement was used because it enhances the transparency and clarity of systematic reviews [251]. The utilization of modern statistical methods to improve the functionality of PROMs has elevated the expectations of instruments beyond robust psychometric properties. As such, the PROMIS standards were adapted for use as they endorse the minimum standards for PROMs used in patient-centered health outcomes and facilitate the development of common metrics for accurate comparisons across conditions, healthcare systems, and geographical locations [252].

This systematic review has some limitations. Firstly, we only included full-text articles in English. Full-text articles were necessary as they are peer-reviewed and recommended by Terwee et al [253]. Nonetheless, the 12 foreign-language articles that would otherwise be eligible for full-text review made up only $3.9 \%$ of the included articles. Secondly, the item bank does not include items developed by the 160 authors $(75.1 \%$ of the articles assessed for inclusion) who either chose not to consent to the inclusion of their PROMs or were uncontactable. Of note, PROMs included in the item bank have adequately captured the concepts measured by the majority of items for which consent was not obtained. To ensure that no range of concepts has been overlooked from the exclusion of the studies, future studies can consider conducting interviews with patients, as well as conducting expert opinion reviews to elicit the conceptual model for medical adherence relevant to the local context. Thirdly, this systematic review only included validation studies of medication adherence PROMs. This was deemed appropriate given the importance of validation in justifying the use of the instrument [254]. Well-validated adherence scales have been strongly correlated with objective measures of adherence [255], allowing accurate and reliable assessment of medication adherence. In addition, expert review and patient feedback were not sought as part of the item evaluation process in this study. As the concept of medical adherence may differ between different sociocultural contexts [256,257], different countries should perform an expert review and gather patient feedback through cognitive interviews based on this item bank to ensure the development of a culturally sensitive instrument to measure medication adherence.

In conclusion, this study has identified and collated the items from 47 unique medication adherence PROMs into an item bank through a systematic review. Researchers are able to select appropriate items from the item bank for the creation of new PROMs. Future research may consider revising and reviewing the items through cognitive interviews, calibrating the items through IRT, and developing a CAT to measure medication adherence precisely.

\section{Acknowledgments}

KYH, WSD, and DHFL contributed equally as co-first authors. TØ, LLL, HBB, and JT contributed equally as senior coauthors.

We would like to thank librarian Ms Wong Suei Nee at the National University of Singapore Medical Library for her advice on search strategies.

This work was supported by the SingHealth Regional Health System (RHS) Population-based, Unified Learning System for Enhanced and Sustainable Health (PULSES) Centre Grant - "Measuring Medication Adherence in Singapore" (CGDec19S03), and PULSES Fellowship (CGDec19F02).

\section{Conflicts of Interest}

None declared.

\section{Multimedia Appendix 1}

Search strategy.

[DOCX File, 32 KB-Multimedia Appendix 1]

\section{Multimedia Appendix 2}

Studies excluded from the item bank due to a lack of consent. [DOCX File, $41 \mathrm{~KB}-$ Multimedia Appendix 2]

\section{Multimedia Appendix 3}

Item mapping of domains and subdomains. 


\section{Multimedia Appendix 4}

Item bank to measure the extent of and reasons for medication adherence.

[DOCX File, 67 KB-Multimedia Appendix 4]

\section{References}

1. Jimmy B, Jose J. Patient medication adherence: measures in daily practice. Oman Med J 2011 May;26(3):155-159 [FREE Full text] [doi: 10.5001/omj.2011.38] [Medline: 22043406]

2. World Health Organization. Adherence to Long-Term Therapies: Evidence For Action. Geneva, Switzerland: World Health Organization 2003:E.

3. DiMatteo MR. Variations in patients' adherence to medical recommendations: a quantitative review of 50 years of research. Med Care 2004 Mar;42(3):200-209. [Medline: 15076819]

4. Gellad WF, Thorpe CT, Steiner JF, Voils CI. The myths of medication adherence. Pharmacoepidemiol Drug Saf 2017 Dec;26(12):1437-1441. [doi: 10.1002/pds.4334] [Medline: 28994158]

5. Balkrishnan R. The importance of medication adherence in improving chronic-disease related outcomes: what we know and what we need to further know. Med Care 2005 Jun;43(6):517-520. [doi: 10.1097/01.mlr.0000166617.68751.5f] [Medline: 15908845]

6. Arnsten JH, Demas PA, Farzadegan H, Grant RW, Gourevitch MN, Chang CJ, et al. Antiretroviral therapy adherence and viral suppression in HIV-infected drug users: comparison of self-report and electronic monitoring. Clin Infect Dis 2001 Oct 15;33(8):1417-1423 [FREE Full text] [doi: 10.1086/323201] [Medline: 11550118]

7. Snyder CF, Jensen RE, Segal JB, Wu AW. Patient-reported outcomes (PROs): putting the patient perspective in patient-centered outcomes research. Med Care 2013 Aug;51(8 Suppl 3):S73-S79 [FREE Full text] [doi: 10.1097/MLR.0b013e31829b1d84] [Medline: 23774513]

8. Mahler C, Hermann K, Horne R, Ludt S, Haefeli WE, Szecsenyi J, et al. Assessing reported adherence to pharmacological treatment recommendations. Translation and evaluation of the Medication Adherence Report Scale (MARS) in Germany. J Eval Clin Pract 2010 Jun;16(3):574-579. [doi: 10.1111/j.1365-2753.2009.01169.x] [Medline: 20210821]

9. Moon SJ, Lee W, Hwang JS, Hong YP, Morisky DE. Accuracy of a screening tool for medication adherence: A systematic review and meta-analysis of the Morisky Medication Adherence Scale-8. PLoS One 2017;12(11):e0187139 [FREE Full text] [doi: 10.1371/journal.pone.0187139] [Medline: 29095870]

10. Song Y, Han H, Song H, Nam S, Nguyen T, Kim MT. Psychometric evaluation of hill-bone medication adherence subscale. Asian Nurs Res (Korean Soc Nurs Sci) 2011 Sep;5(3):183-188 [FREE Full text] [doi: 10.1016/j.anr.2011.09.007] [Medline: 25030368]

11. Voils CI, Maciejewski ML, Hoyle RH, Reeve BB, Gallagher P, Bryson CL, et al. Initial validation of a self-report measure of the extent of and reasons for medication nonadherence. Med Care 2012 Dec;50(12):1013-1019 [FREE Full text] [doi: 10.1097/MLR.0b013e318269e121] [Medline: 22922431]

12. Cappelleri JC, Jason Lundy J, Hays RD. Overview of classical test theory and item response theory for the quantitative assessment of items in developing patient-reported outcomes measures. Clin Ther 2014 May;36(5):648-662 [FREE Full text] [doi: 10.1016/j.clinthera.2014.04.006] [Medline: 24811753]

13. McKenna SP, Heaney A, Wilburn J. Measurement of patient-reported outcomes. 2: Are current measures failing us? J Med Econ 2019 Jun;22(6):523-530. [doi: 10.1080/13696998.2018.1560304] [Medline: 30556787]

14. DeWalt DA, Rothrock N, Yount S, Stone AA, PROMIS Cooperative Group. Evaluation of item candidates: the PROMIS qualitative item review. Med Care 2007 May;45(5 Suppl 1):S12-S21 [FREE Full text] [doi:

10.1097/01.mlr.0000254567.79743.e2] [Medline: 17443114]

15. Luckett T, Butow PN, King MT, Oguchi M, Heading G, Hackl NA, et al. A review and recommendations for optimal outcome measures of anxiety, depression and general distress in studies evaluating psychosocial interventions for English-speaking adults with heterogeneous cancer diagnoses. Support Care Cancer 2010 Oct;18(10):1241-1262. [doi: 10.1007/s00520-010-0932-8] [Medline: 20596731]

16. Jabrayilov R, Emons WHM, Sijtsma K. Comparison of Classical Test Theory and Item Response Theory in Individual Change Assessment. Appl Psychol Meas 2016 Nov;40(8):559-572 [FREE Full text] [doi: 10.1177/0146621616664046] [Medline: 29881070]

17. Weldring T, Smith SMS. Patient-Reported Outcomes (PROs) and Patient-Reported Outcome Measures (PROMs). Health Serv Insights 2013;6:61-68 [FREE Full text] [doi: 10.4137/HSI.S11093] [Medline: 25114561]

18. Kimura T. The impacts of computer adaptive testing from a variety of perspectives. J Educ Eval Health Prof $2017 ; 14: 12$ [FREE Full text] [doi: 10.3352/jeehp.2017.14.12] [Medline: 28552899]

19. Fries JF, Witter J, Rose M, Cella D, Khanna D, Morgan-DeWitt E. Item response theory, computerized adaptive testing, and PROMIS: assessment of physical function. J Rheumatol 2014 Jan;41(1):153-158. [doi: 10.3899/jrheum.130813] [Medline: 24241485]

20. Revicki DA, Cella DF. Health status assessment for the twenty-first century: item response theory, item banking and computer adaptive testing. Qual Life Res 1997 Aug;6(6):595-600. [doi: 10.1023/a:1018420418455] [Medline: 9330558] 
21. Moher D, Liberati A, Tetzlaff J, Altman DG. Preferred reporting items for systematic reviews and meta-analyses: the PRISMA statement. PLoS Med 2009 Jul 21;6(7):e1000097 [FREE Full text] [doi: 10.1371/journal.pmed.1000097] [Medline: $\underline{19621072]}$

22. Cella D, Riley W, Stone A, Rothrock N, Reeve B, Yount S, et al. The Patient-Reported Outcomes Measurement Information System (PROMIS) developed and tested its first wave of adult self-reported health outcome item banks: 2005-2008. J Clin Epidemiol 2010 Nov;63(11):1179-1194 [FREE Full text] [doi: 10.1016/j.jclinepi.2010.04.011] [Medline: 20685078]

23. Terwee CB, Jansma EP, Riphagen II, de Vet HCW. Development of a methodological PubMed search filter for finding studies on measurement properties of measurement instruments. Qual Life Res 2009 Oct;18(8):1115-1123 [FREE Full text] [doi: 10.1007/s11136-009-9528-5] [Medline: 19711195$]$

24. Yap AF, Thirumoorthy T, Kwan YH. Medication adherence in the elderly. Journal of Clinical Gerontology and Geriatrics 2016 Jun;7(2):64-67. [doi: 10.1016/j.jcgg.2015.05.001]

25. Yap AF, Thirumoorthy T, Kwan YH. Systematic review of the barriers affecting medication adherence in older adults. Geriatr Gerontol Int 2016 Oct;16(10):1093-1101. [doi: 10.1111/ggi.12616] [Medline: 26482548]

26. Goh XTW, Tan YB, Thirumoorthy T, Kwan YH. A systematic review of factors that influence treatment adherence in paediatric oncology patients. J Clin Pharm Ther 2017 Feb;42(1):1-7. [doi: 10.1111/jcpt.12441] [Medline: 28045208]

27. Goh H, Kwan YH, Seah Y, Low LL, Fong W, Thumboo J. A systematic review of the barriers affecting medication adherence in patients with rheumatic diseases. Rheumatol Int 2017 Oct;37(10):1619-1628. [doi: 10.1007/s00296-017-3763-9] [Medline: $\underline{28681249]}$

28. Yeam CT, Chia S, Tan HCC, Kwan YH, Fong W, Seng JJB. A systematic review of factors affecting medication adherence among patients with osteoporosis. Osteoporos Int 2018 Dec;29(12):2623-2637. [doi: 10.1007/s00198-018-4759-3] [Medline: 30417253]

29. Fernandez-Lazaro CI, García-González JM, Adams DP, Fernandez-Lazaro D, Mielgo-Ayuso J, Caballero-Garcia A, et al. Adherence to treatment and related factors among patients with chronic conditions in primary care: a cross-sectional study. BMC Fam Pract 2019 Sep 14;20(1):132 [FREE Full text] [doi: 10.1186/s12875-019-1019-3] [Medline: 31521114 ]

30. Herborg H, Haugbølle LS, Sørensen L, Rossing C, Dam P. Developing a generic, individualised adherence programme for chronic medication users. Pharm Pract (Granada) 2008 Jul;6(3):148-157 [FREE Full text] [doi: 10.4321/s1886-36552008000300006] [Medline: 25177406]

31. Jansà M, Hernández C, Vidal M, Nuñez M, Bertran MJ, Sanz S, et al. Multidimensional analysis of treatment adherence in patients with multiple chronic conditions. A cross-sectional study in a tertiary hospital. Patient Educ Couns 2010 Nov;81(2):161-168. [doi: 10.1016/j.pec.2009.12.012] [Medline: 20167450]

32. McLoughlin A, Bennett K, Cahir C. Developing a model of the determinants of medication nonadherence in older community-dwelling patients. Ann Behav Med 2019 Oct 07;53(11):942-954. [doi: 10.1093/abm/kaz004] [Medline: $\underline{30870558]}$

33. Irvine AA, Saunders JT, Blank MB, Carter WR. Validation of scale measuring environmental barriers to diabetes-regimen adherence. Diabetes Care 1990 Jul;13(7):705-711. [doi: 10.2337/diacare.13.7.705] [Medline: 2387191]

34. Lewin AB, LaGreca AM, Geffken GR, Williams LB, Duke DC, Storch EA, et al. Validity and reliability of an adolescent and parent rating scale of type 1 diabetes adherence behaviors: the Self-Care Inventory (SCI). J Pediatr Psychol 2009 Oct;34(9):999-1007 [FREE Full text] [doi: 10.1093/jpepsy/jsp032] [Medline: 19423660]

35. Moss AC, Lillis Y, Edwards George JB, Choudhry NK, Berg AH, Cheifetz AS, et al. Attitudes to mesalamine questionnaire: a novel tool to predict mesalamine nonadherence in patients with IBD. Am J Gastroenterol 2014 Dec;109(12):1850-1855. [doi: 10.1038/ajg.2014.158] [Medline: 24913040]

36. de Oliveira-Filho AD, Morisky DE, Neves SJF, Costa FA, de Lyra DP. The 8-item Morisky Medication Adherence Scale: validation of a Brazilian-Portuguese version in hypertensive adults. Res Social Adm Pharm 2014;10(3):554-561. [doi: 10.1016/j.sapharm.2013.10.006] [Medline: 24268603]

37. Jerant A, DiMatteo R, Arnsten J, Moore-Hill M, Franks P. Self-report adherence measures in chronic illness: retest reliability and predictive validity. Med Care 2008 Nov;46(11):1134-1139. [doi: 10.1097/MLR.0b013e31817924e4] [Medline: 18953223]

38. Dima AL, Schweitzer A, Diaconiţ R, Remor E, Wanless RS. Adherence to ARV medication in Romanian young adults: self-reported behaviour and psychological barriers. Psychol Health Med 2013;18(3):343-354. [doi: 10.1080/13548506.2012.722648] [Medline: 22985131]

39. Dima AL, van Ganse E, Laforest L, Texier N, de Bruin M, The Astro-Lab Group. Measuring medication adherence in asthma: Development of a novel self-report tool. Psychol Health 2017 Oct;32(10):1288-1307. [doi: 10.1080/08870446.2017.1290248] [Medline: 28276742]

40. Najimi A, Mostafavi F, Sharifirad G, Golshiri P. Development and study of self-efficacy scale in medication adherence among Iranian patients with hypertension. J Educ Health Promot 2017;6:83 [FREE Full text] [doi: 10.4103/jehp.jehp 64 16] [Medline: 29114551]

41. Regnault A, Viala-Danten M, Gilet H, Berdeaux G. Scoring and psychometric properties of the Eye-Drop Satisfaction Questionnaire (EDSQ), an instrument to assess satisfaction and compliance with glaucoma treatment. BMC Ophthalmol 2010 Feb 01;10:1 [FREE Full text] [doi: 10.1186/1471-2415-10-1] [Medline: 20122146] 
42. Athavale AS, Bentley JP, Banahan BF, McCaffrey DJ, Pace PF. Preliminary development of the Medication Nonpersistence Scale. J Am Pharm Assoc (2003) 2017;57(3):389-394.e1. [doi: 10.1016/j.japh.2017.01.014] [Medline: 28279599]

43. TURCU- TIOLICA A A. DEVELOPING OF A NEW TOOL FOR EVALUATION OF THERAPEUTIC ADHERENCE IN COPD. FARMACIA 2018 Oct 13;66(5):920-924. [doi: 10.31925/farmacia.2018.5.25]

44. Zeller A, Schroeder K, Peters TJ. An adherence self-report questionnaire facilitated the differentiation between nonadherence and nonresponse to antihypertensive treatment. J Clin Epidemiol 2008 Mar;61(3):282-288. [doi: 10.1016/j.jclinepi.2007.04.007] [Medline: 18226752]

45. Zongo A, Guénette L, Moisan J, Grégoire J. Predictive Validity of Self-Reported Measures of Adherence to Noninsulin Antidiabetes Medication against Control of Glycated Hemoglobin Levels. Can J Diabetes 2016 Feb;40(1):58-65. [doi: 10.1016/j.jcjd.2015.06.008] [Medline: 26507401]

46. Zongo A, Guénette L, Moisan J, Guillaumie L, Lauzier S, Grégoire J. Revisiting the internal consistency and factorial validity of the 8-item Morisky Medication Adherence Scale. SAGE Open Med 2016;4:2050312116674850 [FREE Full text] [doi: 10.1177/2050312116674850] [Medline: 27895914]

47. Zweben A, Piepmeier ME, Fucito L, O'Malley SS. The clinical utility of the Medication Adherence Questionnaire (MAQ) in an alcohol pharmacotherapy trial. J Subst Abuse Treat 2017 Jun;77:72-78 [FREE Full text] [doi: 10.1016/j.jsat.2017.04.001] [Medline: 28476276]

48. Feldman BJ, Fredericksen RJ, Crane PK, Safren SA, Mugavero MJ, Willig JH, et al. Evaluation of the single-item self-rating adherence scale for use in routine clinical care of people living with HIV. AIDS Behav 2013 Jan;17(1):307-318 [FREE Full text] [doi: 10.1007/s10461-012-0326-7] [Medline: 23108721]

49. Jankowska-Polanska B, Uchmanowicz I, Chudiak A, Dudek K, Morisky DE, Szymanska-Chabowska A. Psychometric properties of the Polish version of the eight-item Morisky Medication Adherence Scale in hypertensive adults. Patient Prefer Adherence 2016;10:1759-1766 [FREE Full text] [doi: 10.2147/PPA.S101904] [Medline: 27672314]

50. Svarstad BL, Chewning BA, Sleath BL, Claesson C. The Brief Medication Questionnaire: a tool for screening patient adherence and barriers to adherence. Patient Educ Couns 1999 Jun;37(2):113-124. [doi: 10.1016/s0738-3991(98)00107-4] [Medline: 14528539$]$

51. Resnick B, Wehren L, Orwig D. Reliability and validity of the self-efficacy and outcome expectations for osteoporosis medication adherence scales. Orthop Nurs 2003;22(2):139-147. [doi: 10.1097/00006416-200303000-00012] [Medline: 12703398]

52. Spire B, Arnould B, Barbier F, Durant J, Gilquin J, Landman R, et al. Simplification and first validation of a short battery of patient questionnaires for clinical management of HIV-infected patients: The HIV-SQUAD (Symptom Quality of life Adherence) Questionnaire. HIV Clin Trials 2009;10(4):215-232. [doi: 10.1310/hct1004-215] [Medline: 19723610]

53. De Las Cuevas C, Peñate W. Psychometric properties of the eight-item Morisky Medication Adherence Scale (MMAS-8) in a psychiatric outpatient setting. Int J Clin Health Psychol 2015;15(2):121-129 [FREE Full text] [doi:

10.1016/j.ijchp.2014.11.003] [Medline: 30487829]

54. Brooks CM, Richards JM, Kohler CL, Soong SJ, Martin B, Windsor RA, et al. Assessing adherence to asthma medication and inhaler regimens: a psychometric analysis of adult self-report scales. Med Care 1994 Mar;32(3):298-307. [doi: 10.1097/00005650-199403000-00008] [Medline: $\underline{8145604]}$

55. Tan C, Teng GG, Chong KJ, Cheung PP, Lim A, Wee HL, et al. Utility of the Morisky Medication Adherence Scale in gout: a prospective study. Patient Prefer Adherence 2016;10:2449-2457 [FREE Full text] [doi: 10.2147/PPA.S119719] [Medline: 27980395]

56. Willey C, Redding C, Stafford J, Garfield F, Geletko S, Flanigan T, et al. Stages of change for adherence with medication regimens for chronic disease: development and validation of a measure. Clin Ther 2000 Jul;22(7):858-871. [doi: 10.1016/s0149-2918(00)80058-2] [Medline: 10945512]

57. Lin C, Ou H, Nikoobakht M, Broström A, Årestedt K, Pakpour AH. Validation of the 5-Item Medication Adherence Report Scale in Older Stroke Patients in Iran. J Cardiovasc Nurs 2018;33(6):536-543. [doi: 10.1097/JCN.0000000000000488] [Medline: 29649015]

58. Osborn CY, Gonzalez JS. Measuring insulin adherence among adults with type 2 diabetes. J Behav Med 2016 Aug;39(4):633-641 [FREE Full text] [doi: 10.1007/s10865-016-9741-y] [Medline: 27062271]

59. Morisky DE, Ang A, Krousel-Wood M, Ward HJ. Predictive validity of a medication adherence measure in an outpatient setting. J Clin Hypertens (Greenwich) 2008 May;10(5):348-354 [FREE Full text] [Medline: 18453793]

60. Morisky DE, Green LW, Levine DM. Concurrent and predictive validity of a self-reported measure of medication adherence. Med Care 1986 Jan;24(1):67-74. [Medline: 3945130]

61. Rofail D, Abetz L, Viala M, Gait C, Baladi J, Payne K. Satisfaction and adherence in patients with iron overload receiving iron chelation therapy as assessed by a newly developed patient instrument. Value Health 2009;12(1):109-117 [FREE Full text] [doi: 10.1111/j.1524-4733.2008.00390.x] [Medline: 18637142$]$

62. Shin D, Kim C. Psychometric evaluation of a Korean version of the 8-item Medication Adherence Scale in rural older adults with hypertension. Aust J Rural Health 2013 Dec;21(6):336-342. [doi: 10.1111/ajr.12070] [Medline: 24299439]

63. De GS, Abraham I, Gemoets H, Evers G. Development of the long-term medication behaviour self-efficacy scale: qualitative study for item development. J Adv Nurs 1994 Feb;19(2):233-238. [Medline: 8188953] 
64. de Klerk E, van der Heijde D, van der Tempel H, van der Linden S. Development of a questionnaire to investigate patient compliance with antirheumatic drug therapy. J Rheumatol 1999 Dec;26(12):2635-2641. [Medline: 10606375]

65. Blumberg EJ, Hovell MF, Kelley NJ, Vera AY, Sipan CL, Berg JP. Self-report INH adherence measures were reliable and valid in Latino adolescents with latent tuberculosis infection. J Clin Epidemiol 2005 Jun;58(6):645-648. [doi:

10.1016/j.jclinepi.2004.11.022] [Medline: 15878479 ]

66. Unni EJ, Farris KB. Development of a new scale to measure self-reported medication nonadherence. Res Social Adm Pharm 2015;11(3):e133-e143. [doi: 10.1016/j.sapharm.2009.06.005] [Medline: 21272524]

67. Unni EJ, Olson JL, Farris KB. Revision and validation of Medication Adherence Reasons Scale (MAR-Scale). Curr Med Res Opin 2014 Feb;30(2):211-221. [doi: 10.1185/03007995.2013.851075] [Medline: 24102296]

68. Unni EJ, Sternbach N, Goren A. Using the Medication Adherence Reasons Scale (MAR-Scale) to identify the reasons for non-adherence across multiple disease conditions. Patient Prefer Adherence 2019;13:993-1004 [FREE Full text] [doi: 10.2147/PPA.S205359] [Medline: 31308635]

69. Salt E, Hall L, Peden AR, Home R. Psychometric properties of three medication adherence scales in patients with rheumatoid arthritis. J Nurs Meas 2012;20(1):59-72. [doi: 10.1891/1061-3749.20.1.59] [Medline: 22679710]

70. Tommelein E, Mehuys E, Van Tongelen I, Brusselle G, Boussery K. Accuracy of the Medication Adherence Report Scale (MARS-5) as a quantitative measure of adherence to inhalation medication in patients with COPD. Ann Pharmacother 2014 May;48(5):589-595. [doi: 10.1177/1060028014522982] [Medline: 24523393]

71. Alhomoud F, Alhomoud F, Millar I. How effectively are your patients taking their medicines? A critical review of the Strathclyde Compliance Risk Assessment Tool in relation to the 'MMAS' and 'MARS'. J Eval Clin Pract 2016 Jun;22(3):411-420. [doi: 10.1111/jep.12501] [Medline: 26696012]

72. Vale FC, Santa-Helena ETD, Santos MA, Carvalho WMDES, Menezes PR, Basso CR, et al. Development and validation of the WebAd-Q Questionnaire to monitor adherence to HIV therapy. Rev Saude Publica 2018;52:62 [FREE Full text] [doi: 10.11606/s1518-8787.2018052000337] [Medline: 29846437]

73. Cinar FI, Cinar M, Yilmaz S, Acikel C, Erdem H, Pay S, et al. Cross-Cultural Adaptation, Reliability, and Validity of the Turkish Version of the Compliance Questionnaire on Rheumatology in Patients With Behçet's Disease. J Transcult Nurs 2016 Sep;27(5):480-486. [doi: 10.1177/1043659615577699] [Medline: 25801762]

74. Alsolami FJ, Hou X, Correa-Velez I. An Arabic instrument to Measure Medication Adherence in Saudi Hypertensive Patients. ME-JFM 2013 Sep;11(7):17-23. [doi: 10.5742/mefm.2014.92409]

75. Ortega Suárez FJ, Sánchez Plumed J, Pérez Valentín MA, Pereira Palomo P, Muñoz Cepeda MA, Lorenzo Aguiar D, Grupo de Estudio Vatren. Validation on the simplified medication adherence questionnaire (SMAQ) in renal transplant patients on tacrolimus. Nefrologia 2011;31(6):690-696 [FREE Full text] [doi: 10.3265/Nefrologia.pre2011.Aug.10973] [Medline: $\underline{22130285]}$

76. Julian FS, Martin P, Erickson SR. Validation of the Special Projects of National Significance adherence tool in HIV/AIDS patients. Ann Pharmacother 2010 Jun;44(6):1003-1009. [doi: 10.1345/aph.1M690] [Medline: 20442352]

77. Fabbrini G, Abbruzzese G, Barone P, Antonini A, Tinazzi M, Castegnaro G, REASON study group. Adherence to anti-Parkinson drug therapy in the. Neurol Sci 2013 Nov;34(11):2015-2022. [doi: 10.1007/s10072-013-1438-1] [Medline: 23728715]

78. Fond G, Boyer L, Boucekine M, Aden LA, Schürhoff F, Tessier A, FACE-SZ (FondaMental Academic Centers of Expertise for Schizophrenia) group. Validation study of the Medication Adherence Rating Scale. Results from the FACE-SZ national dataset. Schizophr Res 2017 Apr;182:84-89. [doi: 10.1016/j.schres.2016.10.023] [Medline: 27789187]

79. Owie GO, Olotu SO, James BO. Reliability and validity of the Medication Adherence Rating Scale in a cohort of patients with schizophrenia from Nigeria. Trends Psychiatry Psychother 2018;40(2):85-92 [FREE Full text] [doi: 10.1590/2237-6089-2017-0077] [Medline: 29768528]

80. Ogedegbe G, Mancuso CA, Allegrante JP, Charlson ME. Development and evaluation of a medication adherence self-efficacy scale in hypertensive African-American patients. J Clin Epidemiol 2003 Jun;56(6):520-529. [Medline: 12873646]

81. Cate H, Bhattacharya D, Clark A, Holland R, Broadway DC. A comparison of measures used to describe adherence to glaucoma medication in a randomised controlled trial. Clin Trials 2015 Dec;12(6):608-617. [doi: 10.1177/1740774515592636] [Medline: 26183437]

82. Jónsdóttir H, Opjordsmoen S, Birkenaes AB, Engh JA, Ringen PA, Vaskinn A, et al. Medication adherence in outpatients with severe mental disorders: relation between self-reports and serum level. J Clin Psychopharmacol 2010 Apr;30(2):169-175. [doi: 10.1097/JCP.0b013e3181d2191e] [Medline: 20520290]

83. Cohen HW, Shmukler C, Ullman R, Rivera CM, Walker EA. Measurements of medication adherence in diabetic patients with poorly controlled $\mathrm{HbA}(1 \mathrm{c})$. Diabet Med $2010 \mathrm{Feb}$;27(2):210-216 [FREE Full text] [doi: 10.1111/j.1464-5491.2009.02898.x] [Medline: 20546266]

84. Arnet I, Metaxas C, Walter PN, Morisky DE, Hersberger KE. The 8-item Morisky Medication Adherence Scale translated in German and validated against objective and subjective polypharmacy adherence measures in cardiovascular patients. J Eval Clin Pract 2015 Apr;21(2):271-277. [doi: 10.1111/jep.12303] [Medline: 25558796]

85. Sadakathulla I, Mateti U, Kellarai A, Bhat K. Adhering to antihypertensive treatment is vitally important. Salud(i)Ciencia 2019;23(4):314-324 [FREE Full text] 
86. Zschocke I, Mrowietz U, Lotzin A, Karakasili E, Reich K. Assessing adherence factors in patients under topical treatment: development of the Topical Therapy Adherence Questionnaire (TTAQ). Arch Dermatol Res 2014 Apr;306(3):287-297 [FREE Full text] [doi: 10.1007/s00403-014-1446-x] [Medline: 24509981]

87. Kennedy SB. Developing a self-administered tool to predict adherence to antiretroviral therapy: design, method, and objectives. AIDS Patient Care STDS 2000 Jun;14(6):309-316. [doi: 10.1089/10872910050046331] [Medline: 10897503]

88. Prado JC, Kupek E, Mion D. Validity of four indirect methods to measure adherence in primary care hypertensives. J Hum Hypertens 2007 Jul;21(7):579-584. [doi: 10.1038/sj.jhh.1002196] [Medline: 17443212]

89. George J, Vuong T, Bailey MJ, Kong DC, Marriott JL, Stewart K. Medication Regimen Complexity and Adherence in Patients at Risk of Medication Misadventure. Journal of Pharmacy Practice and Research 2015 Apr 13;36(2):99-102. [doi: 10.1002/j.2055-2335.2006.tb00580.x]

90. Kim J, Lee W, Hong Y, Ryu W, Lee KJ, Lee W, et al. Psychometric properties of a short self-reported measure of medication adherence among patients with hypertension treated in a busy clinical setting in Korea. J Epidemiol 2014;24(2):132-140 [FREE Full text] [doi: 10.2188/jea.je20130064] [Medline: 24463958]

91. Koschack J, Marx G, Schnakenberg J, Kochen MM, Himmel W. Comparison of two self-rating instruments for medication adherence assessment in hypertension revealed insufficient psychometric properties. J Clin Epidemiol 2010 Mar;63(3):299-306. [doi: 10.1016/j.jclinepi.2009.06.011] [Medline: 19762213]

92. Cohen JL, Mann DM, Wisnivesky JP, Home R, Leventhal H, Musumeci-Szabó TJ, et al. Assessing the validity of self-reported medication adherence among inner-city asthmatic adults: the Medication Adherence Report Scale for Asthma. Ann Allergy Asthma Immunol 2009 Oct;103(4):325-331. [Medline: 19852197]

93. Simoni JM, Huh D, Wang Y, Wilson IB, Reynolds NR, Remien RH, et al. The validity of self-reported medication adherence as an outcome in clinical trials of adherence-promotion interventions: Findings from the MACH14 study. AIDS Behav 2014 Dec;18(12):2285-2290 [FREE Full text] [doi: 10.1007/s10461-014-0905-x] [Medline: 25280447]

94. Nordmann J, Denis P, Vigneux M, Trudeau E, Guillemin I, Berdeaux G. Development of the conceptual framework for the Eye-Drop Satisfaction Questionnaire (EDSQ) in glaucoma using a qualitative study. BMC Health Serv Res 2007 Aug 06;7:124 [FREE Full text] [doi: 10.1186/1472-6963-7-124] [Medline: 17683594]

95. Risser J, Jacobson TA, Kripalani S. Development and psychometric evaluation of the Self-efficacy for Appropriate Medication Use Scale (SEAMS) in low-literacy patients with chronic disease. J Nurs Meas 2007;15(3):203-219. [Medline: 18232619$]$

96. van den Boogaard J, Lyimo RA, Boeree MJ, Kibiki GS, Aarnoutse RE. Electronic monitoring of treatment adherence and validation of alternative adherence measures in tuberculosis patients: a pilot study. Bull World Health Organ 2011 Sep 01;89(9):632-639 [FREE Full text] [doi: 10.2471/BLT.11.086462] [Medline: 21897483]

97. Lee JY, Lee SY, Hahn HJ, Son IJ, Hahn SG, Lee EB. Cultural adaptation of a compliance questionnaire for patients with rheumatoid arthritis to a Korean version. Korean J Intern Med 2011 Mar;26(1):28-33 [FREE Full text] [doi: 10.3904/kjim.2011.26.1.28] [Medline: 21437159]

98. Jansà M, Vidal M, Giménez M, Conget I, Galindo M, Roca D, et al. Psychometric analysis of the Spanish and Catalan versions of the Diabetes Self-Care inventory-revised version questionnaire. Patient Prefer Adherence 2013;7:997-1005 [FREE Full text] [doi: 10.2147/PPA.S50271] [Medline: 24124352]

99. Chaiyachati K, Hirschhorn LR, Tanser F, Newell M, Bärnighausen T. Validating five questions of antiretroviral nonadherence in a public-sector treatment program in rural South Africa. AIDS Patient Care STDS 2011 Mar;25(3):163-170 [FREE Full text] [doi: 10.1089/apc.2010.0257] [Medline: 21269131]

100. Wickersham KE, Sereika SM, Kang H, Tamres LK, Erlen JA. Use of a Self-Report Medication Adherence Scale for Measuring Adherence to Antiretroviral Therapy in Patients With HIV/AIDS. J Nurs Meas 2018 Aug;26(2):E72-E88. [doi: 10.1891/1061-3749.26.2.E72] [Medline: 30567952]

101. Kosilov K, Loparev S, Kuzina I, Kosilova L, Ivanovskaya M, Prokofyeva A. Effectiveness of a new tool for self-evaluation of adherence to antimuscarinic drug treatment in older patients of both sexes with urge incontinence. Geriatr Gerontol Int 2018 Jan;18(1):115-122. [doi: 10.1111/ggi.13150] [Medline: 28921819]

102. Kosilov K, Loparev S, Kuzina I, Shakirova O, Zhuravskaya N, Lobodenko A. Self-assessment of treatment compliance with antimuscarinic drugs and lower urinary tract condition among women with urinary incontinence. Int Urogynecol J 2017 Nov;28(11):1663-1669. [doi: 10.1007/s00192-017-3333-4] [Medline: 28429053]

103. Kosilov K, Loparev S, Kuzina I, Shakirova O, Zhuravskaya N, Lobodenko A. The effective tool for self-assessment of adherence to treatment in patients with benign prostatic obstruction and overactive bladder symptoms. Aging Male 2017 Mar;20(1):39-44. [doi: 10.1080/13685538.2016.1247435] [Medline: 28074677]

104. Walewski KM, Cicutto L, D'Urzo AD, Heslegrave RJ, Chapman KR. Evaluation of a questionnaire to assess compliance with anti-asthma medications. J Asthma 2004 Feb;41(1):77-83. [doi: 10.1081/jas-120026064] [Medline: 15046381]

105. Reynolds K, Viswanathan HN, O'Malley CD, Muntner P, Harrison TN, Cheetham TC, et al. Psychometric properties of the Osteoporosis-specific Morisky Medication Adherence Scale in postmenopausal women with osteoporosis newly treated with bisphosphonates. Ann Pharmacother 2012 May;46(5):659-670. [doi: 10.1345/aph.1Q652] [Medline: 22510666]

106. Reynolds K, Viswanathan HN, Muntner P, Harrison TN, Cheetham TC, Hsu JY, et al. Validation of the Osteoporosis-Specific Morisky Medication Adherence Scale in long-term users of bisphosphonates. Qual Life Res 2014 Sep;23(7):2109-2120. [doi: 10.1007/s11136-014-0662-3] [Medline: 24604077] 
107. Thompson K, Kulkarni J, Sergejew AA. Reliability and validity of a new Medication Adherence Rating Scale (MARS) for the psychoses. Schizophr Res 2000 May 5;42(3):241-247. [Medline: 10785582]

108. Kosilov KV, Loparev SA, Kuzina IG, Shakirova OV, Gainullina YI, Kosilova LV, et al. A new tool for self-evaluation of adherence to antimuscarinic drugs treatment in patients with urinary incontinence. Arab J Urol 2017 Dec;15(4):372-379 [FREE Full text] [doi: 10.1016/j.aju.2017.10.007] [Medline: 29234543]

109. Zemmour K, Tinland A, Boucekine M, Girard V, Loubière S, Resseguier N, French Housing First Study Group. Validation of the Medication Adherence Rating Scale in homeless patients with schizophrenia: Results from the French Housing First experience. Sci Rep 2016 Aug 18;6:31598 [FREE Full text] [doi: 10.1038/srep31598] [Medline: 27534796]

110. Kyngäs HA, Skaar-Chandler CA, Duffy ME. The development of an instrument to measure the compliance of adolescents with a chronic disease. J Adv Nurs 2000 Dec;32(6):1499-1506. [doi: 10.1046/j.1365-2648.2000.01611.x] [Medline: 11136419]

111. Fialko L, Garety PA, Kuipers E, Dunn G, Bebbington PE, Fowler D, et al. A large-scale validation study of the Medication Adherence Rating Scale (MARS). Schizophr Res 2008 Mar;100(1-3):53-59. [doi: 10.1016/j.schres.2007.10.029] [Medline: 18083007]

112. Guénette L, Moisan J, Préville M, Boyer R. Measures of adherence based on self-report exhibited poor agreement with those based on pharmacy records. J Clin Epidemiol 2005 Sep;58(9):924-933. [doi: 10.1016/j.jclinepi.2005.02.002] [Medline: $\underline{16085196]}$

113. Lee L, El-Den S, Horne R, Carter SR. Patient satisfaction with information, concerns, beliefs and adherence to topical corticosteroids. Patient Educ Couns 2019 Jun;102(6):1203-1209. [doi: 10.1016/j.pec.2019.01.019] [Medline: 30928342]

114. McDonald-Miszczak L, Maris P, Fitzgibbon T, Ritchie G. A pilot study examining older adults' beliefs related to medication adherence: the BERMA survey. J Aging Health 2004 Nov;16(5):591-614. [doi: 10.1177/0898264304265772] [Medline: 15448274]

115. Nogueira-Silva L, Sá-Sousa A, Lima MJ, Monteiro A, Dennison-Himmelfarb C, Fonseca JA. Translation and cultural adaptation of the Hill-Bone Compliance to High Blood Pressure Therapy Scale to Portuguese. Rev Port Cardiol 2016 Feb;35(2):93-97 [FREE Full text] [doi: 10.1016/j.repc.2015.07.013] [Medline: 26852304]

116. Matza LS, Park J, Coyne KS, Skinner EP, Malley KG, Wolever RQ. Derivation and validation of the ASK-12 adherence barrier survey. Ann Pharmacother 2009 Oct;43(10):1621-1630. [doi: 10.1345/aph.1M174] [Medline: 19776298]

117. Lubinga SJ, Millar I, Babigumira JB. Pilot evaluation of the psychometric properties of a self-medication Risk Assessment Tool among elderly patients in a community setting. BMC Res Notes 2011 Oct 11;4:398 [FREE Full text] [doi: 10.1186/1756-0500-4-398] [Medline: 21989334]

118. Chesney MA, Ickovics JR, Chambers DB, Gifford AL, Neidig J, Zwickl B, PATIENT CARE COMMITTEE \& ADHERENCE. Self-reported adherence to antiretroviral medications among participants in HIV clinical trials: The AACTG Adherence Instruments. AIDS Care 2010 May 27;12(3):255-266. [doi: 10.1080/09540120050042891]

119. Chisholm MA, Lance CE, Williamson GM, Mulloy LL. Development and validation of an immunosuppressant therapy adherence barrier instrument. Nephrol Dial Transplant 2005 Jan;20(1):181-188. [doi: 10.1093/ndt/gfh576] [Medline: 15572384]

120. Ali MAS, Abou-Taleb DAE, Mohamed RR. Treatment adherence and beliefs about medicines among Egyptian vitiligo patients. Dermatol Ther 2016 Nov;29(6):413-418. [doi: 10.1111/dth.12397] [Medline: 27594551]

121. Alsous M, Alhalaiqa F, Abu Farha R, Abdel Jalil M, McElnay J, Horne R. Reliability and validity of Arabic translation of Medication Adherence Report Scale (MARS) and Beliefs about Medication Questionnaire (BMQ)-specific for use in children and their parents. PLoS One 2017;12(2):e0171863 [FREE Full text] [doi: 10.1371/journal.pone.0171863] [Medline: 28192467]

122. Axelsson M, Ekerljung L, Lundbäck B, Lötvall J. Personality and unachieved treatment goals related to poor adherence to asthma medication in a newly developed adherence questionnaire - a population-based study. Multidiscip Respir Med 2016;11:42 [FREE Full text] [doi: 10.1186/s40248-016-0078-8] [Medline: 27980735]

123. DiBonaventura M, Wintfeld N, Huang J, Goren A. The association between nonadherence and glycated hemoglobin among type 2 diabetes patients using basal insulin analogs. Patient Prefer Adherence 2014;8:873-882 [FREE Full text] [doi: 10.2147/PPA.S55550] [Medline: 24971002]

124. Fahey M, Abdulmajeed A, Sabra K. Measurement of Adherence to Anti-Hypertensive Medication as Perceived by Doctors and Patients. Qatar Medical Journal 2006 Jun;2006(1):16. [doi: 10.5339/qmj.2006.1.16]

125. Kikkert MJ, Koeter MWJ, Dekker JJM, Burti L, Robson D, Puschner B, et al. The predictive validity of subjective adherence measures in patients with schizophrenia. Int J Methods Psychiatr Res 2011 Jun;20(2):73-81 [FREE Full text] [doi: 10.1002/mpr.335] [Medline: 21557378]

126. Kleppe M, Lacroix J, Ham J, Midden C. The development of the ProMAS: a Probabilistic Medication Adherence Scale. Patient Prefer Adherence 2015;9:355-367 [FREE Full text] [doi: 10.2147/PPA.S76749] [Medline: 25784791]

127. Krousel-Wood M, Joyce C, Holt EW, Levitan EB, Dornelles A, Webber LS, et al. Development and evaluation of a self-report tool to predict low pharmacy refill adherence in elderly patients with uncontrolled hypertension. Pharmacotherapy 2013 Aug;33(8):798-811 [FREE Full text] [doi: 10.1002/phar.1275] [Medline: 23649849] 
128. Krousel-Wood M, Jannu A, Re RN, Muntner P, Desalvo K. Reliability of a Medication Adherence Measure in an Outpatient Setting. The American Journal of the Medical Sciences 2005 Sep;330(3):128-133. [doi: 10.1097/00000441-200509000-00006]

129. Lu M, Safren SA, Skolnik PR, Rogers WH, Coady W, Hardy H, et al. Optimal recall period and response task for self-reported HIV medication adherence. AIDS Behav 2008 Jan;12(1):86-94. [doi: 10.1007/s10461-007-9261-4] [Medline: 17577653]

130. Nakhaeizadeh M, Khalooei A. Psychometric Properties of Persian Version of the 8-item Morisky Medication Adherence Scale in Type 2 Diabetes Patients. JCDR 2019:YC14-YC18. [doi: 10.7860/jcdr/2019/41408.13076]

131. Saffari M, Zeidi IM, Fridlund B, Chen H, Pakpour AH. A Persian Adaptation of Medication Adherence Self-Efficacy Scale (MASES) in Hypertensive Patients: Psychometric Properties and Factor Structure. High Blood Press Cardiovasc Prev 2015 Sep;22(3):247-255. [doi: 10.1007/s40292-015-0101-8] [Medline: 25986076]

132. Kim MT, Hill MN, Bone LR, Levine DM. Development and Testing of the Hill-Bone Compliance to High Blood Pressure Therapy Scale. Progress in Cardiovascular Nursing 2000 Jun;15(3):90-96. [doi: 10.1111/j.1751-7117.2000.tb00211.x]

133. Mannheimer SB, Mukherjee R, Hirschhorn LR, Dougherty J, Celano SA, Ciccarone D, et al. The CASE adherence index: A novel method for measuring adherence to antiretroviral therapy. AIDS Care 2006 Oct;18(7):853-861 [FREE Full text] [doi: 10.1080/09540120500465160] [Medline: 16971298 ]

134. Duncan NA, Kronenberger WG, Roberson CP, Shapiro AD. VERITAS-PRN: a new measure of adherence to episodic treatment regimens in haemophilia. Haemophilia 2010 Jan;16(1):47-53. [doi: 10.1111/j.1365-2516.2009.02094.x] [Medline: 19754842]

135. Duncan N, Kronenberger W, Roberson C, Shapiro A. VERITAS-Pro: a new measure of adherence to prophylactic regimens in haemophilia. Haemophilia 2010 Mar;16(2):247-255. [doi: 10.1111/j.1365-2516.2009.02129.x] [Medline: 19925631]

136. Reynolds NR, Sun J, Nagaraja HN, Gifford AL, Wu AW, Chesney MA. Optimizing measurement of self-reported adherence with the ACTG Adherence Questionnaire: a cross-protocol analysis. J Acquir Immune Defic Syndr 2007 Dec 01;46(4):402-409. [Medline: 18077832]

137. van de Steeg N, Sielk M, Pentzek M, Bakx C, Altiner A. Drug-adherence questionnaires not valid for patients taking blood-pressure-lowering drugs in a primary health care setting. J Eval Clin Pract 2009 Jun;15(3):468-472. [doi: 10.1111/j.1365-2753.2008.01038.x] [Medline: 19366389]

138. Sowunmi OA, Onifade PO. Psychometric evaluation of medication adherence rating scale (MARS) among Nigerian patients with schizophrenia. Niger J Clin Pract 2019 Sep;22(9):1281-1285 [FREE Full text] [doi: 10.4103/njcp.njcp 325 18] [Medline: 31489867]

139. Kampman O, Lehtinen K, Lassila V. The reliability of compliance assessments performed by doctors and patients during neuroleptic treatment: a comparison of compliance ratings. Acta Psychiatr Scand 2001 Oct;104(4):299-304. [doi: 10.1034/j.1600-0447.2001.00159.x] [Medline: 11722305 ]

140. Marsicano EDO, Fernandes NDS, Colugnati F, Grincenkov FRDS, Fernandes NMDS, De GS, et al. Transcultural adaptation and initial validation of Brazilian-Portuguese version of the Basel assessment of adherence to immunosuppressive medications scale (BAASIS) in kidney transplants. BMC Nephrol 2013 May 21;14:108 [FREE Full text] [doi: 10.1186/1471-2369-14-108] [Medline: 23692889]

141. Pandey A, Raza F, Velasco A, Brinker S, Ayers C, Das SR, et al. Comparison of Morisky Medication Adherence Scale with therapeutic drug monitoring in apparent treatment-resistant hypertension. J Am Soc Hypertens 2015 Jun;9(6):420-426.e2. [doi: 10.1016/j.jash.2015.04.004] [Medline: 26051923]

142. Sakthong P, Chabunthom R, Charoenvisuthiwongs R. Psychometric properties of the Thai version of the 8-item Morisky Medication Adherence Scale in patients with type 2 diabetes. Ann Pharmacother 2009 May;43(5):950-957. [doi: 10.1345/aph.1L453] [Medline: 19366872]

143. Choo PW, Rand CS, Inui TS, Lee ML, Cain E, Cordeiro-Breault M, et al. Validation of patient reports, automated pharmacy records, and pill counts with electronic monitoring of adherence to antihypertensive therapy. Med Care 1999 Sep;37(9):846-857. [Medline: 10493464]

144. Garcia-Marcos PW, Brand PLP, Kaptein AA, Klok T. Is the MARS questionnaire a reliable measure of medication adherence in childhood asthma? J Asthma 2016 Dec;53(10):1085-1089. [doi: 10.1080/02770903.2016.1180699] [Medline: 27177241]

145. Atsuta R, To Y, Sakamoto S, Mukai I, Kobayashi A, Kinoshita A, et al. Assessing usability of the. Allergol Int 2017 Jul;66(3):411-417 [FREE Full text] [doi: 10.1016/j.alit.2016.09.001] [Medline: 27712949]

146. Ayiesah R, Leonard JH, Chong CY. Development and validation of non-adherence to pulmonary rehabilitation questionnaire: a clinical tool for patients with chronic obstructive pulmonary diseases. Clin Ter 2014;165(3):123-128. [doi: 10.7417/CT.2014.1708] [Medline: 24999563]

147. Pedrosa RBDS, Rodrigues RCM. Adaptation and evaluation of the measurement properties of the Brazilian version of the Self-efficacy for Appropriate Medication Adherence Scale. Rev Lat Am Enfermagem 2016;24:e2692 [FREE Full text] [doi: 10.1590/1518-8345.0167.2692] [Medline: 27192417]

148. Rathbun RC, Farmer KC, Lockhart SM, Stephens JR. Validity of a stage of change instrument in assessing medication adherence in indigent patients with HIV infection. Ann Pharmacother 2007 Feb;41(2):208-214. [doi: 10.1345/aph.1H383] [Medline: 17213294] 
149. Fernandes R, Wales S, Crisp J, Kyngas H. Modification and testing of the chronic disease compliance instrument to measure treatment compliance in adolescents with diabetes. J Clin Nurs 2011 May;20(9-10):1273-1281. [doi: 10.1111/j.1365-2702.2010.03566.x] [Medline: 21492273]

150. Jacobsen R, Møldrup C, Christrup L, Sjøgren P, Hansen OB. The Danish version of the Medication Adherence Report Scale: preliminary validation in cancer pain patients. Pain Pract 2009;9(1):1-7. [doi: 10.1111/j.1533-2500.2008.00245.x] [Medline: 19019056]

151. Sampaio R, Azevedo LF, Dias CC, Horne R, Castro Lopes JM. Portuguese version of the Medication Adherence Report Scale (MARS-9): Validation in a population of chronic pain patients. J Eval Clin Pract 2019 Apr;25(2):346-352. [doi: 10.1111/jep.13098] [Medline: $\underline{30648328}$ ]

152. Pedrosa RBDS, Rodrigues RCM, Oliveira HC, Alexandre NMC. Construct Validity of the Brazilian Version of the Self-Efficacy for Appropriate Medication Adherence Scale. J Nurs Meas 2016 Apr 01;24(1):18-31. [doi: 10.1891/1061-3749.24.1.E18] [Medline: 29025523]

153. Kristina SA, Putri LR, Riani DA, Ikawati Z, Endarti D. VALIDITY OF SELF-REPORTED MEASURE OF MEDICATION ADHERENCE AMONG DIABETIC PATIENTS IN INDONESIA. Int Res J Pharm 2019 Aug 2;10(7):144-148. [doi: 10.7897/2230-8407.1007234]

154. Shilbayeh SAR, Almutairi WA, Alyahya SA, Alshammari NH, Shaheen E, Adam A. Validation of knowledge and adherence assessment tools among patients on warfarin therapy in a Saudi hospital anticoagulant clinic. Int J Clin Pharm 2018 Feb;40(1):56-66. [doi: 10.1007/s11096-017-0569-5] [Medline: 29189976]

155. Kalichman SC, Amaral CM, Swetzes C, Jones M, Macy R, Kalichman MO, et al. A simple single-item rating scale to measure medication adherence: further evidence for convergent validity. J Int Assoc Physicians AIDS Care (Chic) 2009;8(6):367-374 [FREE Full text] [doi: 10.1177/1545109709352884] [Medline: 19952289]

156. Kalichman SC, Cain D, Fuhrel A, Eaton L, Di Fonzo K, Ertl T. Assessing medication adherence self-efficacy among low-literacy patients: development of a pictographic visual analogue scale. Health Educ Res 2005 Feb;20(1):24-35. [doi: 10.1093/her/cyg106] [Medline: 15253999]

157. Wilks SE, Spivey CA, Chisholm-Burns MA. Psychometric re-evaluation of the immunosuppressant therapy adherence scale among solid-organ transplant recipients. J Eval Clin Pract 2010 Feb;16(1):64-68. [doi: 10.1111/j.1365-2753.2008.01115.x] [Medline: 20367816]

158. Fernandez S, Chaplin W, Schoenthaler AM, Ogedegbe G. Revision and validation of the medication adherence self-efficacy scale (MASES) in hypertensive African Americans. J Behav Med 2008 Dec;31(6):453-462 [FREE Full text] [doi: 10.1007/s10865-008-9170-7] [Medline: 18784996]

159. Bennett SJ, Milgrom LB, Champion V, Huster GA. Beliefs about medication and dietary compliance in people with heart failure: an instrument development study. Heart Lung 1997;26(4):273-279. [doi: 10.1016/s0147-9563(97)90084-4] [Medline: 9257137]

160. Shalansky SJ, Levy AR, Ignaszewski AP. Self-reported Morisky score for identifying nonadherence with cardiovascular medications. Ann Pharmacother 2004 Sep;38(9):1363-1368. [doi: 10.1345/aph.1E071] [Medline: 15238622]

161. Koneru S, Shishov M, Ware A, Farhey Y, Mongey A, Graham TB, et al. Effectively measuring adherence to medications for systemic lupus erythematosus in a clinical setting. Arthritis Rheum 2007 Aug 15;57(6):1000-1006 [FREE Full text] [doi: 10.1002/art.22898] [Medline: 17665465]

162. Matza LS, Yu-Isenberg KS, Coyne KS, Park J, Wakefield J, Skinner EP, et al. Further testing of the reliability and validity of the ASK-20 adherence barrier questionnaire in a medical center outpatient population. Current Medical Research and Opinion 2008 Oct 14;24(11):3197-3206. [doi: 10.1185/03007990802463642]

163. Mueller S, Wilke T, Gorasso V, Erhart M, Kittner JM. Adaption and validation of the adherence barriers questionnaire for HIV patients on antiretroviral therapy (ABQ-HIV). BMC Infect Dis 2018 Nov 28;18(1):599 [FREE Full text] [doi: 10.1186/s12879-018-3530-x] [Medline: $\underline{\text { 30486795] }}$

164. Müller S, Kohlmann T, Wilke T. Validation of the Adherence Barriers Questionnaire - an instrument for identifying potential risk factors associated with medication-related non-adherence. BMC Health Serv Res 2015 Apr 10;15:153 [FREE Full text] [doi: 10.1186/s12913-015-0809-0] [Medline: 25884193]

165. Okello S, Nasasira B, Muiru ANW, Muyingo A. Validity and Reliability of a Self-Reported Measure of Antihypertensive Medication Adherence in Uganda. PLoS One 2016;11(7):e0158499 [FREE Full text] [doi: 10.1371/journal.pone.0158499] [Medline: 27367542]

166. Hahn SR, Park J, Skinner EP, Yu-Isenberg KS, Weaver MB, Crawford B, et al. Development of the ASK-20 adherence barrier survey. Curr Med Res Opin 2008 Jul;24(7):2127-2138. [doi: 10.1185/03007990802174769] [Medline: 18554431]

167. Smith SR, Wahed AS, Kelley SS, Conjeevaram HS, Robuck PR, Fried MW, Virahep-C Study Group. Assessing the validity of self-reported medication adherence in hepatitis C treatment. Ann Pharmacother 2007 Jul;41(7):1116-1123. [doi: 10.1345/aph.1K024] [Medline: 17519299]

168. Sidorkiewicz S, Tran V, Cousyn C, Perrodeau E, Ravaud P. Development and validation of an instrument to assess treatment adherence for each individual drug taken by a patient. BMJ Open 2016 May 10;6(5):e010510 [FREE Full text] [doi: 10.1136/bmjopen-2015-010510] [Medline: 27165645] 
169. Sriwarakorn S, Krittiyanunt S, Sakulbumrungsil R. Sensitivity and specificity of Thai-version brief medication questionnaire. Journal of Health Research 2010;24(3):129-134 [FREE Full text]

170. Stjernswärd S, Persson K, Nielsen R, Tuninger E, Levander S. A modified Drug Attitude Inventory used in long-term patients in sheltered housing. Eur Neuropsychopharmacol 2013 Oct;23(10):1296-1299. [doi: 10.1016/j.euroneuro.2012.11.011] [Medline: 23265955]

171. Ashur ST, Shamsuddin K, Shah SA, Bosseri S, Morisky DE. Reliability and known-group validity of the Arabic version of the 8-item Morisky Medication Adherence Scale among type 2 diabetes mellitus patients. East Mediterr Health J 2015 Dec 13;21(10):722-728 [FREE Full text] [doi: 10.26719/2015.21.10.722] [Medline: 26750162]

172. Wales S, Crisp J, Fernandes R, Kyngas H. Modification and testing of the chronic disease compliance instrument to measure treatment compliance in adolescents with asthma. Contemp Nurse 2011 Oct;39(2):147-156. [doi: 10.5172/conu.2011.147] [Medline: 22551427]

173. Kerr T, Hogg RS, Yip B, Tyndall MW, Montaner J, Wood E. Validity of self-reported adherence among injection drug users. J Int Assoc Physicians AIDS Care (Chic) 2008;7(4):157-159. [doi: 10.1177/1545109708320686] [Medline: 18626123]

174. Mumtaz T, Haider SA, Malik JA, La Greca AM. Translation, validation and effectiveness of self-care inventory in assessing adherence to diabetes treatment. J Pak Med Assoc 2016 Jul;66(7):853-858 [FREE Full text] [Medline: 27427135]

175. Giordano TP, Guzman D, Clark R, Charlebois ED, Bangsberg DR. Measuring adherence to antiretroviral therapy in a diverse population using a visual analogue scale. HIV Clin Trials 2004;5(2):74-79. [doi: 10.1310/JFXH-G3X2-EYM6-D6UG] [Medline: 15116282]

176. Hogan TP, Awad AG, Eastwood R. A self-report scale predictive of drug compliance in schizophrenics: reliability and discriminative validity. Psychol Med 1983 Feb;13(1):177-183. [Medline: 6133297]

177. Phillips T, Brittain K, Mellins CA, Zerbe A, Remien RH, Abrams EJ, et al. A Self-Reported Adherence Measure to Screen for Elevated HIV Viral Load in Pregnant and Postpartum Women on Antiretroviral Therapy. AIDS Behav 2017 Feb;21(2):450-461 [FREE Full text] [doi: 10.1007/s10461-016-1448-0] [Medline: 27278548]

178. Andy UU, Harvie HS, Smith AL, Propert KJ, Bogner HR, Arya LA. Validation of a self-administered instrument to measure adherence to anticholinergic drugs in women with overactive bladder. Neurourol Urodyn 2015 Jun;34(5):424-428 [FREE Full text] [doi: 10.1002/nau.22605] [Medline: 24719232]

179. Breuil V, Cortet B, Cotté F, Arnould B, Dias-Barbosa C, Gaudin A, et al. Validation of the adherence evaluation of osteoporosis treatment (ADEOS) questionnaire for osteoporotic post-menopausal women. Osteoporos Int 2012 Feb;23(2):445-455 [FREE Full text] [doi: 10.1007/s00198-011-1555-8] [Medline: 21625889]

180. Korb-Savoldelli V, Gillaizeau F, Pouchot J, Lenain E, Postel-Vinay N, Plouin P, et al. Validation of a French version of the 8-item Morisky medication adherence scale in hypertensive adults. J Clin Hypertens (Greenwich) 2012 Jul;14(7):429-434 [FREE Full text] [doi: 10.1111/j.1751-7176.2012.00634.x] [Medline: 22747615]

181. Vreeman RC, Nyandiko WM, Ayaya SO, Walumbe EG, Inui TS. Cognitive interviewing for cross-cultural adaptation of pediatric antiretroviral therapy adherence measurement items. Int J Behav Med 2014 Feb;21(1):186-196. [doi: 10.1007/s12529-012-9283-9] [Medline: 23188670]

182. Da W, Li X, Qiao S, Zhou Y, Shen Z. Evaluation of self-report adherence measures and their associations with detectable viral load among people living with HIV (PLHIV) in China. PLoS One 2018;13(8):e0203032 [FREE Full text] [doi: 10.1371/journal.pone.0203032] [Medline: 30161177]

183. Doucette WR, Farris KB, Youland KM, Newland BA, Egerton SJ, Barnes JM. Development of the Drug Adherence Work-up (DRAW) tool. J Am Pharm Assoc (2003) 2012;52(6):e199-e204. [doi: 10.1331/JAPhA.2012.12001] [Medline: 23945734]

184. Lee W, Ahn J, Kim J, Hong Y, Hong SK, Kim YT, et al. Reliability and validity of a self-reported measure of medication adherence in patients with type 2 diabetes mellitus in Korea. J Int Med Res 2013 Aug;41(4):1098-1110. [doi: 10.1177/0300060513484433] [Medline: 23860015]

185. He W, Bonner A, Anderson D. Patient reported adherence to hypertension treatment: A revalidation study. European Journal of Cardiovascular Nursing 2015 Aug 25;15(2):150-156. [doi: 10.1177/1474515115603902]

186. Kao Y, Liu Y. Compliance and schizophrenia: the predictive potential of insight into illness, symptoms, and side effects. Compr Psychiatry 2010;51(6):557-565. [doi: 10.1016/j.comppsych.2010.03.007] [Medline: 20965300]

187. Kim Y, Evangelista LS, Phillips LR, Pavlish C, Kopple JD. The End-Stage Renal Disease Adherence Questionnaire (ESRD-AQ): testing the psychometric properties in patients receiving in-center hemodialysis. Nephrol Nurs $\mathbf{J}$ 2010;37(4):377-393. [Medline: 20830945]

188. Wang Y, Lee J, Toh MPHS, Tang WE, Ko Y. Validity and reliability of a self-reported measure of medication adherence in patients with Type 2 diabetes mellitus in Singapore. Diabet Med 2012 Sep;29(9):e338-e344. [doi: 10.1111/j.1464-5491.2012.03733.x] [Medline: 22672497]

189. Wang Y, Kong MC, Ko Y. Psychometric properties of the 8-item Morisky Medication Adherence Scale in patients taking warfarin. Thromb Haemost 2012 Oct;108(4):789-795. [doi: 10.1160/TH12-05-0368] [Medline: 22836920]

190. Garfield S, Eliasson L, Clifford S, Willson A, Barber N. Developing the Diagnostic Adherence to Medication Scale (the DAMS) for use in clinical practice. BMC Health Serv Res 2012 Oct 08;12:350 [FREE Full text] [doi:

10.1186/1472-6963-12-350] [Medline: 23039138] 
191. Gökdoğan F, Kes D. Validity and reliability of the Turkish Adherence to Refills and Medications Scale. Int J Nurs Pract 2017 Oct;23(5):532-538. [doi: 10.1111/ijn.12566] [Medline: 28726281]

192. Kripalani S, Risser J, Gatti ME, Jacobson TA. Development and evaluation of the Adherence to Refills and Medications Scale (ARMS) among low-literacy patients with chronic disease. Value Health 2009;12(1):118-123 [FREE Full text] [doi: 10.1111/j.1524-4733.2008.00400.x] [Medline: 19911444]

193. Chui E, Wong KL, Chan KY, Wong M. Validation study of the Brief Medication Adherence Scale (BMAS) in patients with schizophrenia and related disorders in Hong Kong. Asian J Psychiatr 2018 Oct;37:154-160. [doi: 10.1016/j.ajp.2018.09.005] [Medline: $\underline{\text { 30265964] }}$

194. Cornelius T, Voils CI, Umland RC, Kronish IM. Validity Of The Self-Reported Domains Of Subjective Extent Of Nonadherence (DOSE-Nonadherence) Scale In Comparison With Electronically Monitored Adherence To Cardiovascular Medications. Patient Prefer Adherence 2019;13:1677-1684 [FREE Full text] [doi: 10.2147/PPA.S225460] [Medline: 31631982]

195. Blalock DV, Zullig LL, Bosworth HB, Taylor SS, Voils CI. Self-reported medication nonadherence predicts cholesterol levels over time. J Psychosom Res 2019 Mar;118:49-55. [doi: 10.1016/j.jpsychores.2019.01.010] [Medline: 30782354]

196. Liau YW, Cheow C, Leung KTY, Tan H, Low SF, Cheen HHM, et al. A cultural adaptation and validation study of a self-report measure of the extent of and reasons for medication nonadherence among patients with diabetes in Singapore. Patient Prefer Adherence 2019;13:1241-1252 [FREE Full text] [doi: 10.2147/PPA.S208736] [Medline: 31551654]

197. Fairley CK, Permana A, Read TRH. Long-term utility of measuring adherence by self-report compared with pharmacy record in a routine clinic setting. HIV Med 2005 Sep;6(5):366-369 [FREE Full text] [doi: 10.1111/j.1468-1293.2005.00322.x] [Medline: $\underline{16156886}$ ]

198. Naqvi AA, AlShayban DM, Ghori SA, Mahmoud MA, Haseeb A, Faidah HS, et al. Validation of the General Medication Adherence Scale in Saudi Patients With Chronic Diseases. Front Pharmacol 2019;10:633 [FREE Full text] [doi: 10.3389/fphar.2019.00633] [Medline: 31231222]

199. Naqvi AA, Hassali MA, Jahangir A, Nadir MN, Kachela B. Translation and validation of the English version of the general medication adherence scale (GMAS) in patients with chronic illnesses. J Drug Assess 2019;8(1):36-42 [FREE Full text] [doi: 10.1080/21556660.2019.1579729] [Medline: $\underline{30863660]}$

200. Naqvi AA, Hassali MA, Rizvi M, Zehra A, Iffat W, Haseeb A, et al. Development and Validation of a Novel General Medication Adherence Scale (GMAS) for Chronic Illness Patients in Pakistan. Front Pharmacol 2018;9:1124 [FREE Full text] [doi: 10.3389/fphar.2018.01124] [Medline: 30356775$]$

201. Athavale AS, Bentley JP, Banahan BF, McCaffrey DJ, Pace PF, Vorhies DW. Development of the medication adherence estimation and differentiation scale (MEDS). Curr Med Res Opin 2019 Apr;35(4):577-585. [doi: 10.1080/03007995.2018.1512478] [Medline: 30106315]

202. Lee S, Bae YH, Worley M, Law A. Validating the Modified Drug Adherence Work-Up (M-DRAW) Tool to Identify and Address Barriers to Medication Adherence. Pharmacy (Basel) 2017 Sep 08;5(3):50-52 [FREE Full text] [doi: 10.3390/pharmacy5030052] [Medline: 28970464]

203. Lee S, Bae-Shaaw YH, Gogineni H, Worley MM, Law AV. Triple strength utility of the Modified Drug Adherence Work-Up (M-DRAW) tool in a veterans affairs outpatient diabetes clinic. Res Social Adm Pharm 2019 Oct 01:914-920. [doi: 10.1016/j.sapharm.2019.09.063] [Medline: 31629655]

204. Muñoz-Moreno JA, Fumaz CR, Ferrer MJ, Tuldrà A, Rovira T, Viladrich C, SERAD Validation Team. Assessing self-reported adherence to HIV therapy by questionnaire: the SERAD (Self-Reported Adherence) Study. AIDS Res Hum Retroviruses 2007 Oct;23(10):1166-1175. [doi: 10.1089/aid.2006.0120] [Medline: 17961100]

205. Knobel H, Alonso J, Casado JL, Collazos J, González J, Ruiz I, et al. Validation of a simplified medication adherence questionnaire in a large cohort of HIV-infected patients: the GEEMA Study. AIDS 2002 Mar 8;16(4):605-613. [Medline: $\underline{11873004]}$

206. Wilson IB, Fowler FJ, Cosenza CA, Michaud J, Bentkover J, Rana A, et al. Cognitive and field testing of a new set of medication adherence self-report items for HIV care. AIDS Behav 2014 Dec;18(12):2349-2358 [FREE Full text] [doi: 10.1007/s10461-013-0610-1] [Medline: 24077970]

207. Wilson IB, Lee Y, Michaud J, Fowler FJ, Rogers WH. Validation of a New Three-Item Self-Report Measure for Medication Adherence. AIDS Behav 2016 Nov;20(11):2700-2708 [FREE Full text] [doi: 10.1007/s10461-016-1406-x] [Medline: 27098408]

208. Ueno H, Yamazaki Y, Yonekura Y, Park MJ, Ishikawa H, Kiuchi T. Reliability and validity of a 12-item medication adherence scale for patients with chronic disease in Japan. BMC Health Serv Res 2018 Jul 31;18(1):592 [FREE Full text] [doi: 10.1186/s12913-018-3380-7] [Medline: 30064422]

209. Hughes LD, Done J, Young A. A 5 item version of the Compliance Questionnaire for Rheumatology (CQR5) successfully identifies low adherence to DMARDs. BMC Musculoskelet Disord 2013 Oct 08;14:286 [FREE Full text] [doi: 10.1186/1471-2474-14-286] [Medline: 24103582]

210. Schatz M, Zeiger RS, Yang S, Weinstein AG, Chen W, Saris-Baglama RN, et al. Development and preliminary validation of the Adult Asthma Adherence Questionnaire ${ }^{\text {TM }}$. J Allergy Clin Immunol Pract 2013;1(3):280-288. [doi: 10.1016/j.jaip.2013.03.001] [Medline: 24565486] 
211. Gabriel A, Violato C. Knowledge of and attitudes towards depression and adherence to treatment: the Antidepressant Adherence Scale (AAS). J Affect Disord 2010 Nov;126(3):388-394. [doi: 10.1016/j.jad.2010.07.013] [Medline: 20708273]

212. Martins MJRV, Pinto AM, Castilho P, Macedo AF, Pereira AT, Bajouco M, et al. Assessing beliefs and attitudes towards antipsychotic medication from a recovery-based perspective: Psychometric properties of a new scale. Psychiatry Res 2019 Mar;273:325-330. [doi: 10.1016/j.psychres.2019.01.043] [Medline: 30677722]

213. Demirtaş A, Akbayrak N. Development of an assessment scale for treatment compliance in type 2 Diabetes Mellitus in Turkish population: Psychometric evaluation. Int J Nurs Sci 2017 Jul 10;4(3):244-251 [FREE Full text] [doi: 10.1016/j.ijnss.2017.06.002] [Medline: 31406748]

214. Dolder CR, Lacro JP, Warren KA, Golshan S, Perkins DO, Jeste DV. Brief evaluation of medication influences and beliefs: development and testing of a brief scale for medication adherence. J Clin Psychopharmacol 2004 Aug;24(4):404-409. [doi: 10.1097/01.jcp.0000130554.63254.3a] [Medline: 15232332]

215. Tan J, Luo L, Zhang M, Chen H, Zhang D, Dong C, et al. A Chinese and Western medication adherence scale in patients with Chronic Kidney Disease. Patient Prefer Adherence 2019;13:1487-1495 [FREE Full text] [doi: 10.2147/PPA.S207693] [Medline: $\underline{31507316}$ ]

216. Zheng J, Wang Y, Ye X, Xiao L, Ye J, Li X, et al. Validation of diabetes medication self-efficacy scale in Chinese with type 2 diabetes. Patient Prefer Adherence 2018;12:2517-2525 [FREE Full text] [doi: 10.2147/PPA.S170144] [Medline: $\underline{30568430}$ ]

217. Kerr SJ, Avihingsanon A, Putcharoen O, Chetchotisakd P, Layton M, Ubolyam S, et al. Assessing adherence in Thai patients taking combination antiretroviral therapy. Int J STD AIDS 2012 Mar;23(3):160-165. [doi: 10.1258/ijsa.2009.009152] [Medline: 22581867]

218. Mehta SN, Nansel TR, Volkening LK, Butler DA, Haynie DL, Laffel LMB. Validation of a contemporary adherence measure for children with Type 1 diabetes: the Diabetes Management Questionnaire. Diabet Med 2015 Sep;32(9):1232-1238 [FREE Full text] [doi: 10.1111/dme.12682] [Medline: 26280463]

219. Sleath B, Carpenter DM, Blalock SJ, Davis SA, Hickson RP, Lee C, et al. Development of a new diabetes medication self-efficacy scale and its association with both reported problems in using diabetes medications and self-reported adherence. Patient Prefer Adherence 2016;10:1003-1010 [FREE Full text] [doi: 10.2147/PPA.S101349] [Medline: 27354769]

220. Vreeman RC, Scanlon ML, Tu W, Slaven JE, McAteer CI, Kerr SJ, et al. Validation of a self-report adherence measurement tool among a multinational cohort of children living with HIV in Kenya, South Africa and Thailand. J Int AIDS Soc 2019 May;22(5):e25304 [FREE Full text] [doi: 10.1002/jia2.25304] [Medline: 31148372]

221. Jesus-Nunes AP, Morais-de-Jesus M, Dantas-Duarte A, Moreira TM, Argolo FC, Castro ADO, et al. The Portuguese Version of the Immunosuppressant Therapy Adherence Scale (ITAS) among Liver Transplant Recipient Patients: Translation and Psychometric Properties. Ann Hepatol 2018;17(1):104-109 [FREE Full text] [doi: 10.5604/01.3001.0010.7541] [Medline: 29311393]

222. Mikhael EM, Hussain SA, Shawky N, Hassali MA. Validity and reliability of anti-diabetic medication adherence scale among patients with diabetes in Baghdad, Iraq: a pilot study. BMJ Open Diabetes Res Care 2019;7(1):e000658 [FREE Full text] [doi: 10.1136/bmjdrc-2019-000658] [Medline: 31354953]

223. Wohl DA, Panter AT, Kirby C, Magnus BE, Hudgens MG, Allmon AG, et al. Estimating HIV Medication Adherence and Persistence: Two Instruments for Clinical and Research Use. AIDS Behav 2018 Mar;22(3):948-960. [doi: 10.1007/s10461-017-1772-z] [Medline: 28447269]

224. Nelsen A, Trautner BW, Petersen NJ, Gupta S, Rodriguez-Barradas M, Giordano TP, et al. Development and validation of a measure for intention to adhere to HIV treatment. AIDS Patient Care STDS 2012 Jun;26(6):329-334 [FREE Full text] [doi: 10.1089/apc.2011.0318] [Medline: 22680281]

225. Gonzalez JS, Schneider HE, Wexler DJ, Psaros C, Delahanty LM, Cagliero E, et al. Validity of medication adherence self-reports in adults with type 2 diabetes. Diabetes Care 2013 Apr;36(4):831-837 [FREE Full text] [doi: 10.2337/dc12-0410] [Medline: 23204245]

226. Battistella M, Fleites R, Wong R, Jassal SV. Development, validation, and implementation of a medication adherence survey to seek a better understanding of the hemodialysis patient. Clin Nephrol 2016 Jan;85(1):12-22. [doi: 10.5414/CN108654] [Medline: 26636327]

227. Wicks P, Massagli M, Kulkarni A, Dastani H. Use of an online community to develop patient-reported outcome instruments: the Multiple Sclerosis Treatment Adherence Questionnaire (MS-TAQ). J Med Internet Res 2011;13(1):e12 [FREE Full text] [doi: 10.2196/jmir.1687] [Medline: 21266318]

228. Qi B, Resnick B. Reliability and validity of the Chinese versions of self-efficacy and outcome expectations for osteoporosis medication adherence scales in Chinese immigrants. J Nurs Meas 2014;22(3):472-488. [doi: 10.1891/1061-3749.22.3.472] [Medline: 25608433]

229. Fredericksen RJ, Yang FM, Gibbons LE, Edwards TC, Brown S, Fitzsimmons E, et al. Development and content validation of measures assessing adherence barriers and behaviors for use in clinical care. Res Social Adm Pharm 2019 Sep;15(9):1168-1176. [doi: 10.1016/j.sapharm.2018.10.001] [Medline: 30327183] 
230. Almeida-Brasil CC, Nascimento ED, Silveira MR, Bonolo PDF, Ceccato MDGB. New patient-reported outcome measure to assess perceived barriers to antiretroviral therapy adherence: the PEDIA scale. Cad Saude Publica 2019;35(5):e00184218 [FREE Full text] [doi: 10.1590/0102-311x00184218] [Medline: $\underline{31166419}$ ]

231. Poveda V, Amado L, Filgueiras M, Teixeira L, Miranda V, Santos-Silva A, et al. End-stage renal disease adherence questionnaire: translation and validation to the portuguese language. Ren Fail 2016 Nov;38(10):1633-1638. [doi: 10.1080/0886022X.2016.1209063] [Medline: 27764984]

232. Teixeira A, Oliveira C, Teixeira M, Rita Gaio A, Lobo JMS, de Almeida IFM, et al. Development and Validation of a Novel Questionnaire for Adherence with Topical Treatments in Psoriasis (QATOP). Am J Clin Dermatol 2017 Aug;18(4):571-581. [doi: 10.1007/s40257-017-0272-2] [Medline: 28321796]

233. Abe RY, Wen LDC, Barker GT, Mansberger SL. Psychometric Properties of the Glaucoma Treatment Compliance Assessment Tool (GTCAT) in a Brazilian Population. J Glaucoma 2018 Mar;27(3):257-265. [doi: 10.1097/IJG.0000000000000876] [Medline: 29369851]

234. Barker GT, Mansberger SL. Psychometric Properties of the Reduced Version of the Glaucoma Treatment Compliance Assessment Tool (GTCAT). Ophthalmic Epidemiol 2019 Feb;26(1):55-62. [doi: 10.1080/09286586.2018.1516785] [Medline: $\underline{30204034]}$

235. Kandrotaite K, Smigelskas K, Janusauskiene D, Jievaltas M, Maciulaitis R, Briedis V. Development of a short questionnaire to identify the risk of nonadherence to antibiotic treatment. Curr Med Res Opin 2013 Nov;29(11):1555-1563. [doi: 10.1185/03007995.2013.835255] [Medline: 23952367]

236. Daouphars M, Ouvry M, Lenain P, Rouvet J, Jardin F, Bubenheim M, et al. Preliminary validation of self-assessment tool to measure imatinib adherence in patients with chronic myeloid leukemia. Pharmacotherapy 2013 Feb;33(2):152-156. [doi: 10.1002/phar.1174] [Medline: 23359430]

237. Buscher A, Hartman C, Kallen MA, Giordano TP. Validity of self-report measures in assessing antiretroviral adherence of newly diagnosed, HAART-naïve, HIV patients. HIV Clin Trials 2011;12(5):244-254 [FREE Full text] [doi: 10.1310/hct1205-244] [Medline: 22180522]

238. Erickson SR, Coombs JH, Kirking DM, Azimi AR. Compliance from self-reported versus pharmacy claims data with metered-dose inhalers. Ann Pharmacother 2001 Sep;35(9):997-1003. [doi: 10.1345/aph.10379] [Medline: 11573875]

239. Godin G, Gagné C, Naccache H. Validation of a self-reported questionnaire assessing adherence to antiretroviral medication. AIDS Patient Care STDS 2003 Jul;17(7):325-332. [doi: 10.1089/108729103322231268] [Medline: 12952734]

240. Plaza V, Fernández-Rodríguez C, Melero C, Cosío BG, Entrenas LM, de LLP, et al. Validation of the 'Test of the Adherence to Inhalers' (TAI) for Asthma and COPD Patients. J Aerosol Med Pulm Drug Deliv 2016 Apr;29(2):142-152 [FREE Full text] [doi: 10.1089/jamp.2015.1212] [Medline: 26230150]

241. Mancebo MC, Pinto A, Rasmussen SA, Eisen JL. Development of the Treatment Adherence Survey-patient version (TAS-P) for OCD. J Anxiety Disord 2008;22(1):32-43 [FREE Full text] [doi: 10.1016/j.janxdis.2007.01.009] [Medline: 17324553]

242. Cella D, Gershon R, Lai J, Choi S. The future of outcomes measurement: item banking, tailored short-forms, and computerized adaptive assessment. Qual Life Res 2007;16 Suppl 1:133-141. [doi: 10.1007/s11136-007-9204-6] [Medline: 17401637]

243. Kripalani S, Gatti ME, Jacobson TA. Association of age, health literacy, and medication management strategies with cardiovascular medication adherence. Patient Educ Couns 2010 Nov;81(2):177-181. [doi: 10.1016/j.pec.2010.04.030] [Medline: 20684870]

244. Eindhoven DC, Hilt AD, Zwaan TC, Schalij MJ, Borleffs CJW. Age and gender differences in medical adherence after myocardial infarction: Women do not receive optimal treatment - The Netherlands claims database. Eur J Prev Cardiol 2018 Jan;25(2):181-189. [doi: 10.1177/2047487317744363] [Medline: 29164916]

245. Lai J, Dineen K, Reeve BB, Von Roenn J, Shervin D, McGuire M, et al. An item response theory-based pain item bank can enhance measurement precision. J Pain Symptom Manage 2005 Sep;30(3):278-288 [FREE Full text] [doi: 10.1016/j.jpainsymman.2005.03.009] [Medline: 16183012]

246. Haley SM, Ni P, Hambleton RK, Slavin MD, Jette AM. Computer adaptive testing improved accuracy and precision of scores over random item selection in a physical functioning item bank. J Clin Epidemiol 2006 Nov;59(11):1174-1182. [doi: 10.1016/j.jclinepi.2006.02.010] [Medline: 17027428]

247. Inui TS, Carter WB, Pecoraro RE, Pearlman RA, Dohan JJ. Variations in patient compliance with common long-term drugs. Med Care 1980 Oct;18(10):986-993. [doi: 10.1097/00005650-198010000-00002] [Medline: 7453267]

248. Piette JD, Heisler M, Ganoczy D, McCarthy JF, Valenstein M. Differential medication adherence among patients with schizophrenia and comorbid diabetes and hypertension. Psychiatr Serv 2007 Feb;58(2):207-212. [doi: 10.1176/ps.2007.58.2.207] [Medline: 17287377]

249. Lai J, Cella D, Chang C, Bode RK, Heinemann AW. Item banking to improve, shorten and computerize self-reported fatigue: an illustration of steps to create a core item bank from the FACIT-Fatigue Scale. Qual Life Res 2003 Aug;12(5):485-501. [Medline: 13677494]

250. Dirven L, Groenvold M, Taphoorn MJB, Conroy T, Tomaszewski KA, Young T, EORTC Quality of Life Group. Psychometric evaluation of an item bank for computerized adaptive testing of the EORTC QLQ-C30 cognitive functioning dimension in cancer patients. Qual Life Res 2017 Nov;26(11):2919-2929 [FREE Full text] [doi: 10.1007/s11136-017-1648-8] [Medline: $\underline{28707048]}$ 
251. Liberati A, Altman DG, Tetzlaff J, Mulrow C, Gøtzsche PC, Ioannidis JPA, et al. The PRISMA statement for reporting systematic reviews and meta-analyses of studies that evaluate health care interventions: explanation and elaboration. J Clin Epidemiol 2009 Oct;62(10):e1-34 [FREE Full text] [doi: 10.1016/j.jclinepi.2009.06.006] [Medline: 19631507]

252. Evans JP, Smith A, Gibbons C, Alonso J, Valderas JM. The National Institutes of Health Patient-Reported Outcomes Measurement Information System (PROMIS): a view from the UK. Patient Relat Outcome Meas 2018;9:345-352 [FREE Full text] [doi: 10.2147/PROM.S141378] [Medline: 30498382]

253. Terwee CB, Prinsen CAC, Ricci GMG, Suman A, de VHCW, Mokkink LB. The quality of systematic reviews of health-related outcome measurement instruments. Qual Life Res 2016 Apr;25(4):767-779 [FREE Full text] [doi: 10.1007/s11136-015-1122-4] [Medline: 26346986]

254. Kubica A, Kosobucka A, Michalski P, Fabiszak T, Felsmann M. Self-reported questionnaires for assessment adherence to treatment in patients with cardiovascular diseases. Medical Research Journal 2018 Mar 30;2(4):115-122. [doi:

10.5603/MRJ.2017.0015]

255. Nguyen T, La CA, Cottrell N. What are validated self-report adherence scales really measuring?: a systematic review. Br J Clin Pharmacol 2014 Mar;77(3):427-445 [FREE Full text] [doi: 10.1111/bcp.12194] [Medline: 23803249]

256. Jin L, Acharya L. Cultural Beliefs Underlying Medication Adherence in People of Chinese Descent in the United States. Health Commun 2016;31(5):513-521. [doi: 10.1080/10410236.2014.974121] [Medline: 26422467]

257. McQuaid EL, Landier W. Cultural Issues in Medication Adherence: Disparities and Directions. J Gen Intern Med 2018 Feb;33(2):200-206 [FREE Full text] [doi: 10.1007/s11606-017-4199-3] [Medline: 29204971]

\author{
Abbreviations \\ CAT: computer-adaptive tests \\ DOSE-Nonadherence: Domains of Subjective Extent of Nonadherence \\ IRT: item response theory \\ PROMs: patient-reported outcome measures \\ PRISMA: Preferred reporting items for systematic review and meta-analysis \\ PROMIS: Patient-Reported Outcomes Measurement Information System
}

Edited by G Eysenbach; submitted 07.04.20; peer-reviewed by P Nieuwkerk, S Wee, T Patel; comments to author 08.06.20; revised
version received 12.06.20; accepted 14.06.20; published 08.10.20
Please cite as:
Kwan YH, Oo LJY, Loh DHF, Phang JK, Weng SD, Blalock DV, Chew EH, Yap KZ, Tan CYK, Yoon S, Fong W, Østbye T, Low LL,
Bosworth HB, Thumboo J
Development of an Item Bank to Measure Medication Adherence: Systematic Review
J Med Internet Res 2020;22(10):e19089
URL: https://www.jmir.org/2020/10/e19089
doi: $\underline{10.2196 / 19089}$
PMID: $\underline{33030441}$

(C) Yu Heng Kwan, Livia Jia Yi Oo, Dionne Hui Fang Loh, Jie Kie Phang, Si Dun Weng, Dan V Blalock, Eng Hui Chew, Kai Zhen Yap, Corrinne Yong Koon Tan, Sungwon Yoon, Warren Fong, Truls Østbye, Lian Leng Low, Hayden Barry Bosworth, Julian Thumboo. Originally published in the Journal of Medical Internet Research (http://www.jmir.org), 08.10.2020. This is an open-access article distributed under the terms of the Creative Commons Attribution License (https://creativecommons.org/licenses/by/4.0/), which permits unrestricted use, distribution, and reproduction in any medium, provided the original work, first published in the Journal of Medical Internet Research, is properly cited. The complete bibliographic information, a link to the original publication on http://www.jmir.org/, as well as this copyright and license information must be included. 